\title{
Upwellings mitigated Plio-Pleistocene heat stress for reef corals on the Florida platform (USA)
}

\author{
Thomas C. Brachert ${ }^{1}$, Markus Reuter ${ }^{2}$, Stefan Krüger ${ }^{1}$, Julia Kirkerowicz ${ }^{1}$, and James S. Klaus ${ }^{3}$ \\ ${ }^{1}$ Institut für Geophysik und Geologie, Universität Leipzig, Leipzig, Germany \\ ${ }^{2}$ Institut für Erdwissenschaften, Karl Franzens Universität Graz, Graz, Austria \\ ${ }^{3}$ Department of Geological Sciences, University of Miami, Coral Gables, Florida, USA
}

Correspondence to: T. C. Brachert (brachert@uni-leipzig.de)

Received: 12 September 2015 - Published in Biogeosciences Discuss.: 14 October 2015

Revised: 4 February 2016 - Accepted: 17 February 2016 - Published: 10 March 2016

\begin{abstract}
The fast growing calcareous skeletons of zooxanthellate reef corals ( $\mathrm{z}$ corals) represent unique environmental proxy archives through their oxygen and carbon stable isotope composition $\left(\delta^{18} \mathrm{O}, \delta^{13} \mathrm{C}\right)$. In addition, the accretion of the skeleton itself is ultimately linked to the environment and responds with variable growth rates (extension rate) and density to environmental changes. Here we present classical proxy data $\left(\delta^{18} \mathrm{O}, \delta^{13} \mathrm{C}\right)$ in combination with calcification records from 15 massive $\mathrm{z}$ corals. The $\mathrm{z}$ corals were sampled from four interglacial units of the Florida carbonate platform (USA) dated approximately 3.2, 2.9, 1.8 and $1.2 \mathrm{Ma}$ (middle Pliocene to early Pleistocene). The z corals (Solenastrea, Orbicella, Porites) derive from unlithified shallow marine carbonates and were carefully screened for primary preservation suited for proxy analysis. We show that skeletal accretion responded with decreasing overall calcification rates (decreasing extension rate but increasing density) to warmer water temperatures. Under high annual water temperatures, inferred from sub-annually resolved $\delta^{18} \mathrm{O}$ data, skeletal bulk density was high, but extension rates and overall calcification rates were at a minimum (endmember scenario 1). Maximum skeletal density was reached during the summer season giving rise to a growth band of high density within the annually banded skeletons ("high density band", HDB). With low mean annual water temperatures (endmember scenario 2), bulk skeletal density was low but extension rates and calcification rates reached a maximum, and under these conditions the HDB formed during winter. Although surface water temperatures in the Western Atlantic warm pool during the interglacials of the late Neogene were $\sim 2{ }^{\circ} \mathrm{C}$ higher than they are in the present day, intermittent upwelling of cool,
\end{abstract}

nutrient-rich water mitigated water temperatures off southwestern Florida and created temporary refuges for $\mathrm{z}$ coral growth. Based on the sub-annually resolved $\delta^{18} \mathrm{O}$ and $\delta^{13} \mathrm{C}$ records, the duration of the upwelling episodes causing the endmember 2 conditions was variable and lasted from a few years to a number of decades. The episodes of upwelling were interrupted by phases without upwelling (endmember 1) which lasted for at least a few years and led to high surface water temperatures. This variable environment is likely one of the reasons why the coral fauna is dominated by the eurytopic genus Solenastrea, also a genus resistant to high turbidity. Over a period of $\sim 50$ years, the oldest sub annually resolved proxy record available (3.2 Ma) documents a persistent occurrence of the HDB during winter. In contrast, the HDB forms in summer in modern $\mathrm{z}$ corals from the Florida reef tract. We suggest this difference should be tested as being the expression of a tendency towards decreasing interglacial upwelling since the middle Pliocene. The number of $\mathrm{z}$ coral sclerochronological records for the Plio-Pleistocene is still rather low, however, and requires more data and an improved resolution, through records from additional time slices. Nonetheless, our calcification data from the warm periods of past interglacials may contribute to predicting the effects of future ocean warming on $\mathrm{z}$ coral health along the Florida reef tract. The inconsistent timing of the HDB within single coral records or among specimens and time slices is unexpected and contrasts the common practice of establishing chronologies on the basis of the density banding. 


\section{Introduction}

The skeletons of photosymbiotic, zooxanthellate corals (z corals) are highly organised, porous structures formed of the mineral aragonite $\left(\mathrm{CaCO}_{3}\right)$. Main structures include the tubular corallites in which the living polyps reside, and (in some taxa) the bulbous coenosteum between the corallites which is covered by a thin layer of living organic tissue. The architecture of the corallites is complicated by a well-defined wall and radially arranged blades (septa), sometimes more or less axially fused to form a columnar structure within the centre (columella), and laterally fused, convex upward sheets (dissepiments) which serve to separate the living tissue from abandoned parts of the skeleton. Representatives of $\mathrm{z}$ corals having this type of organization are the genera Orbicella and Solenastrea. In Porites, the spongy aspect of the skeletal architecture results from laterally fused tiny corallites with perforated walls and irregularly arranged dissepiments. In X-ray images of slices parallel to the axes of the corallites (axes of maximum growth), the skeletons of both groups of massive $\mathrm{z}$ corals display alternating light and dark bands, the "density bands", which reflect zones of different skeletal density concordant with successive upward growth and former growth stages (Knutson et al., 1972). The origin of the rhythmic density changes has been suggested to have two underlying causes: (i) variations in the density of packing of the sclerodermites at the micro-architectural level, and/or (ii) thickness of the meso-scale skeletal structural elements (septa, costae, columnellae) relative to porosity remaining open (Buddemeier et al., 1974; Dodge et al., 1992; Le Tissier et al., 1994). In the Orbicella-type skeleton, the density banding is very pronounced and sharply defined, reflecting the thickness of exothecal structural elements (dissepiments, costae), but not variations in their spacing, whereas it is the overall thickness of the skeletal structures and/or size-variability of the pore spaces and likely also micro-structural organization within the spongy skeleton and/or the thickness of the tissue layer which causes the density bands in Porites (Dodge et al., 1992; Le Tissier et al., 1994; Reuter et al., 2005).

A pair of high and low density bands is generally assumed to represent 1 year of growth and forms the basis for the calibration of internal age models and estimates of rates of annual upward and outward growth of the colony surface (extension rate $\left[\mathrm{cm} \mathrm{yr}^{-1}\right.$ ]; (Knutson et al., 1972; Lough and Cooper, 2011). Density is a measure of the thickness of the skeletal elements and the total amount of pore volumes (measured as $\mathrm{g} \mathrm{cm}^{-3}$ ): the thicker and more massive the individual skeletal elements and the smaller the pores, the higher and closer the density will be to that of the mineral aragonite $\left(2.9 \mathrm{~g} \mathrm{~cm}^{-3}\right)$. The two parameters, extension rate and density, combine for estimates of calcification rates according to Eq. (1; Lough and Cooper, 2011):

$$
\begin{aligned}
& \text { calcification rate }\left(\mathrm{g} \mathrm{cm}^{-2} \mathrm{yr}^{-1}\right) \\
& =\text { annual extension rate }\left(\mathrm{cm} \mathrm{yr}^{-1}\right) \times \text { density }\left(\mathrm{g} \mathrm{cm}^{-3}\right)
\end{aligned}
$$

Although a pair of density bands typically corresponds with 1 year of growth, no universal pattern of band formation and timing of the high density (HDB) and low density (LDB) bands over the seasonal cycle has been found among reef sites world-wide (Highsmith, 1979). Many examples of missing bands or additional bands ("stress bands") and sequences of double HDBs (dHDB) have been reported (Brachert et al., 2013; Dodge et al., 1992; Highsmith, 1979; Leder et al., 1991; Lough and Cooper, 2011; Worum et al., 2007). More recent studies have shown the systematics of calcification to differ among taxa and ocean regions. While temperature tends to boost calcification rates in recent $\mathrm{z}$ corals, temperature effects on extension rate and density markedly differ (Carricart-Ganivet, 2004; Elizalde-Rendon et al., 2010; Lough, 2008; Norzagary-Lopez et al., 2014). In the IndoPacific genus Porites, linear extension rate shows a significant increase with sea-water temperature but a concomitant decrease in bulk skeletal density (Lough, 2008). Importantly, however, extension rates have been shown to decline at unusually high temperatures (Cantin et al., 2010; De'ath et al., 2009, 2013). In Orbicella from the Western Atlantic, relationships of skeletal growth with ambient water temperature are less clear. In the Gulf of Mexico and Caribbean Sea, linear extension rates decline when skeletal bulk density increases with temperature (Carricart-Ganivet, 2004). In Atlantic Porites (Elizalde-Rendon et al., 2010) the response of linear extension with temperature agrees with that of Porites from the Indo-Pacific, but no temperature effect on bulk density is evident (Elizalde-Rendon et al., 2010). It has been suggested, therefore, that the calcification strategies of the two coral genera and their species differ with regard to successfully colonising space on a reef. Likely, Orbicella is adapted to high-latitude settings by investing more of their calcification resources into linear extension rather than thickening, i.e. "sacrificing density" in order to occupy space on a reef efficiently near the lower temperature threshold of distribution (Carricart-Ganivet, 2004). In addition to the environment, gender seems to represent another poorly understood component controlling calcification (Cabral-Tena et al., 2013).

Some evidence has been documented that calcification does not respond in a linear way to temperature or environmental changes in general (Worum et al., 2007). In one study using stable isotope data from fossil Porites (9-10 Ma), inconsistent subannual timing of the HDB-LDB rhythms among specimens and within individual specimens has been observed, i.e. shifts in the timing of the HDB from the summer to the winter season and the presence of double HDBs in a single year (Brachert et al., 2013). The reasons for this variable timing of the HDB in $\mathrm{z}$ corals of the same coral taxon at any given site of growth remains poorly known, but may represent the effect of multiple environmental factors acting in concert on non-linear calcification responses (Brachert et al., 2013). One of these factors has been shown to be water depth, i.e. the timing of the HDB varies with water depth (Klein et al., 1992). Here we present seasonally resolved sta- 
ble isotope records from fossil $\mathrm{z}$ corals in combination with data on their calcification history. This study aims at constraining the environment of growth and the annual and seasonal water temperatures on the Florida carbonate platform during some Pliocene and Pleistocene interglacials and how these factors controlled skeletal calcification in $\mathrm{z}$ corals. We discuss the calcification signatures with regard to upwelling and the fate of coral calcification along the Florida reef tract with continued global warming. This study complements a previous study on long-term seasonality recorded by Florida corals and mollusks (Brachert et al., 2014) and forms the basis for a companion paper on fossil $\mathrm{z}$ coral calcification rates (Brachert et al., 2015).

\subsection{Stratigraphy and oceanography of the Florida Platform}

The Neogene Florida platform represents a stack of depositional units forming marginal wedges or rather continuous sheets over the southern part of the peninsula. The units are comprised of shallow-marine skeletal carbonate deposits and date from interglacials when seal levels were up to $35 \mathrm{~m}$ above present (Dowsett and Cronin, 1990; Miller et al., 2012). Intercalated freshwater sediments and paleosols formed during glacial sea level lowstands (Jones et al., 1991; Petuch and Roberts, 2007). At some time, an extensive reef system existed along the south-eastern margin of the platform, associated with a complex system of platform interior environments (Meeder, 1979). Details of the facies, the biota, and the palaeogeography of the single stratigraphic units are described elsewhere (Allmon, 1992; Banks, 1967; Brachert et al., 2014; DuBar, 1958; Locker and Doyle, 1992; Meeder, 1979; Petuch, 1982; Petuch and Roberts, 2007).

Modern surface hydrology around the Florida peninsula differs substantially on the Gulf and Atlantic sides. On the western shelf, SSTs are strongly linked with winter coolings of the northern Gulf of Mexico and range approximately between 17 to $32^{\circ} \mathrm{C}$. This contrasts with a more subdued seasonal SST cycle along the eastern coast ranging between 22 to $30^{\circ} \mathrm{C}$. This pattern is modified during El Niño/La Niña events and positive and/or negative phases of the North Atlantic Oscillation (NAO) causing either wet and cool or dry and warm deviations from seasonal average (Böcker, 2014). Upwelling occurs episodically and intermittently on both sides of the peninsula and depends on the prevalent seasonal wind systems and the strength of the Loop Current (LC) and Florida Current (FC) systems (Fernald and Purdum, 1981). On the eastern side, upwelling occurs during summer, in connection with an intensified FC (Fernald and Purdum, 1981; Pitts and Smith, 1997; Yang, 1999), whereas on the western Florida shelf, more sustained upwellings occur in winter and respond essentially to an intensified LC and wind-assisted Ekman transport. A concomitant shoaling of the thermocline in the LC causes an intrusion of sub-surface water onto the shelf and shallow water zones (Li and Weisberg, 1999).

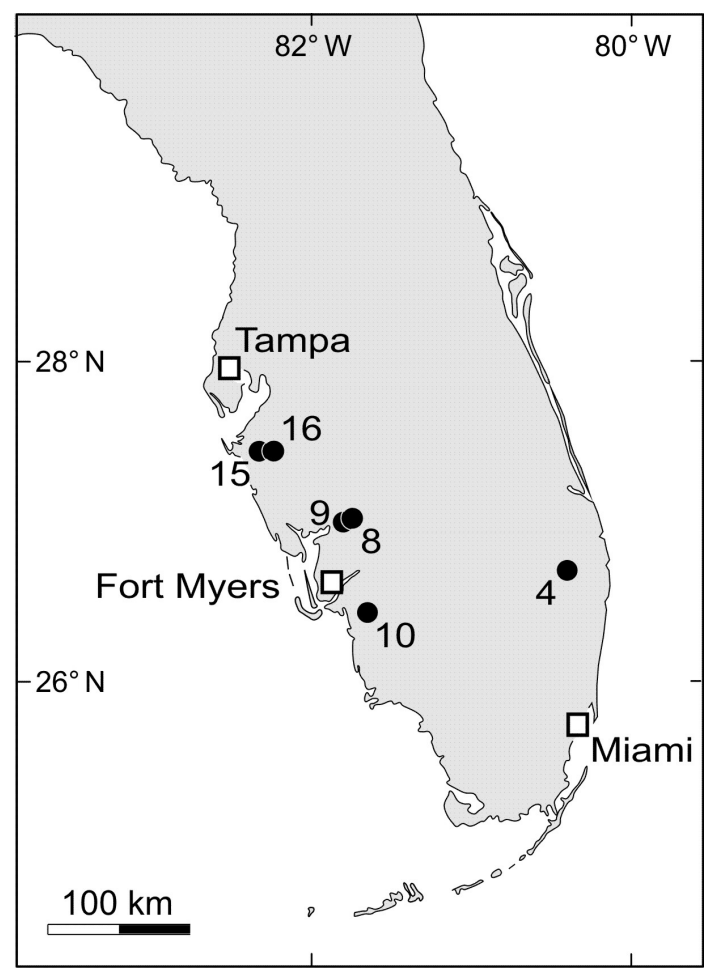

Figure 1. Sampling stations in southern Florida, USA (dots). See Table 1 for details and numbering of sampling stations.

\subsection{Materials}

The $\mathrm{z}$ corals studied derive from four chronostratigraphic units of the Florida carbonate platform representing interglacial highstands of sea level and spanning collectively the period from the middle Pliocene to the early Pleistocene (Table 1). Sampling sites in southern Florida selected for this study are pits for carbonate gravels and de-watering canals exposing carbonate sediments with well-established stratigraphic position (middle Pliocene to early Pleistocene; Fig. 1, Table 1). Most of the fossil samples were taken years ago by Edward Petuch (Boca Raton, USA) when the gravel pits were dry through pumping and allowed for documenting and sampling exactly according to stratigraphic position. In order to improve the database for the present study, this material was complemented by one specimen described in the literature (Roulier and Quinn, 1995) and additional specimens collected by our group from spoil piles adjacent to the gravel pits and canals because the outcrops are presently flooded with groundwater. Materials from spoil piles are reworked and sediments not in their original stratigraphic position, though all fossils from the spoils were considered to derive from the stratigraphic unit exposed on site. Collections are dominated by specimens of Solenastrea $(n=12)$, but also include Orbicella $(n=2)$ and Porites $(n=1)$, both as entire coralla $(<20 \mathrm{~cm})$ and fragments of large coralla $(<60 \mathrm{~cm})$. The scleractinian genus name Orbicella is used for corals 
Table 1. Sampling sites in southern Florida. The numbering follows Brachert et al. (2014).

\begin{tabular}{|c|c|c|c|c|c|}
\hline No. & Site & Sample ID & GPS coordinates & Lithostratigraphy & $\begin{array}{l}\text { Age } \\
(\mathrm{Ma})\end{array}$ \\
\hline 4 & $\begin{array}{l}\text { Palm Beach } \\
\text { Aggregates }\end{array}$ & $\begin{array}{l}\text { EP8 } \\
\text { EP9A } \\
\text { EP9C } \\
\text { EP9D }\end{array}$ & $\begin{array}{l}26^{\circ} 41.742^{\prime} \mathrm{N} \\
80^{\circ} 21.270^{\prime} \mathrm{W}\end{array}$ & $\begin{array}{l}\text { Bermont Fm. } \\
\text { (Holey Land Mb.) }\end{array}$ & 1.2 \\
\hline 8 & $\begin{array}{l}\text { Brantley Pit, } \\
\text { Arcadia }\end{array}$ & EP6-S2 & $\begin{array}{l}27^{\circ} 2.988^{\circ} \mathrm{N} \\
81^{\circ} 49.611^{\prime} \mathrm{W}\end{array}$ & $\begin{array}{l}\text { Caloosahatchee Fm. } \\
\text { (Bee Branch Mb.) }\end{array}$ & 1.8 \\
\hline 9 & $\begin{array}{l}\text { DeSoto Sand } \\
\text { and Shell LLC } \\
\text { (site 452) }\end{array}$ & $\begin{array}{l}452-\mathrm{K} 1-\mathrm{S} 6 \\
452-\mathrm{K} 4-\mathrm{S} 1 \\
452-\mathrm{K} 14-\mathrm{S} 6\end{array}$ & $\begin{array}{l}27^{\circ} 3.587^{\prime} \mathrm{N} \\
81^{\circ} 47.627^{\prime} \mathrm{W}\end{array}$ & $\begin{array}{l}\text { Caloosahatchee Fm } \\
\text { (Bee Branch Mb.) }\end{array}$ & 1.8 \\
\hline 10 & $\begin{array}{l}\text { unnamed pit } \\
\text { (site 509) }\end{array}$ & $509 \mathrm{~A}$ & $\begin{array}{l}26^{\circ} 27.149^{\prime} \mathrm{N} \\
81^{\circ} 42.988^{\prime} \mathrm{W}\end{array}$ & Caloosahatchee Fm. & 1.8 \\
\hline 15 & $\begin{array}{l}\text { Mule Pen } \\
\text { Quarry }\end{array}$ & $\begin{array}{l}\text { EP1-S2 } \\
\text { EP2-S2 } \\
\text { EP3 } \\
\text { EP4-S2 } \\
\text { EP5-S2 }\end{array}$ & $\begin{array}{l}26^{\circ} 10.410^{\prime} \mathrm{N} \\
81^{\circ} 42.468^{\prime} \mathrm{W}\end{array}$ & $\begin{array}{l}\text { Tamiami Fm. (Golden Gate Mb.) } \\
\text { (Golden Gate Mb.) }\end{array}$ & 2.9 \\
\hline 16 & $\begin{array}{l}\text { Quality Aggregates } \\
\text { (APAC) }\end{array}$ & Coral $\# 1^{2}$ & N/A & $\begin{array}{l}\text { Tamiami Fm. } \\
\text { (Pinecrest Mb., unit 7) }\end{array}$ & 3.2 \\
\hline
\end{tabular}

${ }^{1}$ From Böcker (2014), ${ }^{2}$ from Roulier and Quinn (1995).

previously assigned to the Montastraea annularis group according to the revised taxonomic classification of the reef coral family Mussidae (Budd et al., 2012).

\subsection{Methods}

The fossil corals $(n=15$, Table 1$)$ were cut into slabs of $<1 \mathrm{~cm}$ thickness along the plane of maximum growth using a conventional rock saw at lowest speed and equipped with a water-cooled diamond blade. All corals were screened for diagenetic alteration using a binocular microscope and SEM. In order to detect minimal contaminations by secondary calcite, powder samples taken at random were prepared for Xray diffraction (XRD) and analysed using a Rigaku Miniflex diffractometer with scanning angles of 20 to $60^{\circ} 2 \theta$. The detection limit of the method is $\sim 1 \%$. Only skeletal areas that retained their original aragonite mineralogy, skeletal porosity and microstructure with no evidence for significant secondary crystal growth or dissolution (microscopic and SEM observation) were accepted for further analyses. Coral slabs of equal thickness were $\mathrm{X}$-rayed using a digital $\mathrm{X}$-ray cabinet (SHR $50 \mathrm{~V}$ ) to identify potential zones of diagenetic alteration (McGregor and Gagan, 2003; Reuter et al., 2005) and to document cyclic density variations, i.e. the density bands (Knutson et al., 1972). Density bands were defined visually along the zones of maximum change in the grey scale of the radiographs.

Quantitative measurements of density were made using Xray densitometry (Helmle et al., 2002). Measurements were undertaken along transects parallel to the corallites and par- allel to the isotope transects (see below). The individual measurement transects were carefully selected so as not to cross secondary cavities resulting from bioerosion, e.g. borings from bivalves, and potential zones of diagenetic alteration. Bulk skeletal density was calculated as the mean of all individual measurements along a given transect. Calibration of the measurements was tested by measurements of standards for zero density (air) and massive aragonite (slice of an aragonitic bivalve shell having a thickness equaling that of the coral slice). External analytical precision was tested by multiple measurements, and mean deviation from regression $\left(R^{2}=0.9\right)$ was found to be $0.04 \pm 0.01 \mathrm{~g} \mathrm{~cm}^{-3}$ (range $\left.0.02-0.06 \mathrm{~g} \mathrm{~cm}^{-3}\right)$, i.e. better than $5 \%$. All quantitative data of density and linear extension are given as mean values and standard deviations $( \pm 1 \sigma)$.

$\mathrm{Z}$ coral stable isotope data described here are the same as reported by Brachert et al. (2014) supplemented by data from two additional Solenastrea samples (Table 1). Sample powders for stable isotope analysis were taken using a microdrill fixed to a manually operated $\mathrm{X} / \mathrm{Y} / \mathrm{Z}$ table. A $0.6 \mathrm{~mm}$ drill bit and a drilling depth of $1 \mathrm{~mm}$ yielded $>20 \mu \mathrm{g}$ of sample powder from the theca wall. Sampled corallites were selected according to their orientation parallel to the surface of the coral slices in order to avoid geometric distortions between stable isotope cycles and the density bands (Le Tissier et al., 1994). For sampling of the corallite wall, all endothecal skeletal elements such as septae, columella and endothecal dissepiments were removed prior to sampling using a handheld microdrill. For technical reasons, we sampled the inner surface of the corallite wall instead of its external side (en- 
dothecate sampling method of Leder et al., 1996). Sampling the cleaned inner surface of the corallite wall assured all potentially existent secondary overgrowths (early or late diagenetic cements) were removed prior to sampling. Samples for isotopic analysis were taken at equal distances of $0.5 \mathrm{~mm}$ (or $0.7 \mathrm{~mm}$ for coral sample $452 \mathrm{~K} 1$ ). In Porites we used a simplified technique where the sample drilling was made without prior cleaning of inner corallite surfaces. Our sampling approach assured the calculation of annual extension rates on the basis of the number of samples per oxygen isotope year. Oxygen isotope years for the age models were defined by the most positive $\delta^{18} \mathrm{O}$ values assuming them to reflect maximum winter conditions. The age models were further refined by linear interpolation of sampling points between winter values (Brachert et al., 2006a). One long Solenastrea $\delta^{18} \mathrm{O}$ record was spliced together from four overlapping transects along parallel corallites using the software package AnalySeries (Paillard et al., 1996). In order to document the relationships of stable isotope data with the density bands, steel balls were placed within some of the drill holes of the sampling path and the coral slices X-rayed again.

Oxygen and carbon stable isotope analyses were carried out at the Institute of Geophysics and Geology, Leipzig University. Carbonate powders were reacted with $102 \%$ phosphoric acid at $70^{\circ} \mathrm{C}$ using a Kiel IV online carbonate preparation line connected to a MAT 253 mass spectrometer. All carbonate values are reported in per mil (\%o) relative to the PDB standard according to the delta notation. Reproducibility was checked by replicate analysis of laboratory standards and was better than $\pm 0.04 \%$ o $(1 \sigma)$ for carbon $\left(\delta^{13} \mathrm{C}\right)$ and better than $\pm 0.06 \%$ o $(1 \sigma)$ for oxygen isotopes $\left(\delta^{18} \mathrm{O}\right)$. Water values of $\delta^{18} \mathrm{O}_{\mathrm{w}}$ are reported vs. SMOW. The seasonal difference in $\delta^{18} \mathrm{O}$ values is given as Delta - delta values $\left(\Delta \delta^{18} \mathrm{O}\right)$. For calculations of paleotemperatures, we followed the methodology described by Leder et al. (1996). SMOW to PDB conversions were made according to the relationships given by Friedman and O'Neil (1977).

Statistical analyses were performed using the PAST palaeontological statistics software package (version 3.01) for education and data analysis (freeware folk.uio.no/ohammer/past/). Stable isotope data $\left(\delta^{18} \mathrm{O}\right.$, $\delta^{13} \mathrm{C}$ ) were evaluated using the $t$ test. A linear bivariate model was tested as to whether there were no statistical differences in the stable isotope values in a data set $(p>0.05)$ against the alternate hypothesis that there were significant differences $(p<0.05)$. Equality of regression slopes was tested using the $f$ test as assumed by analyses of covariance (ANCOVA).

\section{Results}

\subsection{Macroscopic and microscopic aspect of the coral samples}

In outcrop, coral specimens were selected according to the retention of all anatomical features of the corallites and a low weight taken to imply the absence of secondary cements and mineral transformation and/or recrystallisation. Upon microscopic investigation using SEM (Fig. 2a-g), the skeletons display stacked spherulites or fans and layers of fibrous aragonite which represent the microstructures typical of scleractinian corals (Constantz, 1986; Nothdurft and Webb, 2007). Within the centres of the single calcifying units (sclerodermites), porosity is more or less enhanced and the aragonite crystallites are particularly small, granular in shape and have no preferential orientation (Fig. 2b, c, e). The fiber crystals of the sclerodermites display bladed or platy morphologies (Fig. 2e), whereas fibers with beaded shape and rounded crystal rims (Fig. 2c) enclosing submicron-sized, rounded channels at crystal contacts are of minor abundance (Fig. $2 \mathrm{~g}$ ).

XRD analyses of the skeletons documented $100 \%$ aragonite with no measurable amount of secondary calcite. Also, in stereo-microscope and SEM view, skeletal surfaces are smooth and devoid of syntaxial overgrowths or continuous crusts of secondary incrustations of cement (Fig. 2a, d, f), except for rare patches of isopachous or radial aragonite cement occurring at random within a few specimens and rare biogenic incrustations (Böcker, 2014). Near-surface, open, straight tubular cavity systems, commonly Y-branched, with diameters $<5 \mu \mathrm{m}$ and parallel to skeletal surfaces (Fig. 2d) are less than $1 \%$ by volume and probably caused by endolithic fungi (Nothdurft and Webb, 2007).

Interpretation: XRD analyses did not reveal any measurable amount of calcite which agrees with the results of microscopic and radiographic visual inspections documenting no significant amounts of secondary calcite cements. Early marine aragonite cements representing common modifiers of skeletal porosity in recent $\mathrm{z}$ corals (Nothdurft and Webb, 2009) have not been recorded on a regular basis in our material and represent rare occurrences of patches of small spherulites rather than isopachous rims of acicular cement (Böcker, 2014). Thus, precipitation of secondary cement was volumetrically not important, neither at sea floor as aragonite or magnesium calcite, nor as calcite formed during late stages of diagenesis.

Enhanced porosity at the centres of calcification (Fig. 2b) and channels along crystal boundaries, rounded crystal rims, and tiny beaded crystals within the centres of calcification are all potential effects of post-mortem dissolution (Fig. 2c, g). Evidence for secondary aragonite-aragonite transformations (Perrin, 2004) has not been observed in SEM. Taken together, all cements and possible dissolution features are never volumetrically important as to visibly blur the density bands documented in X-radiographs (see below). For this reason, 

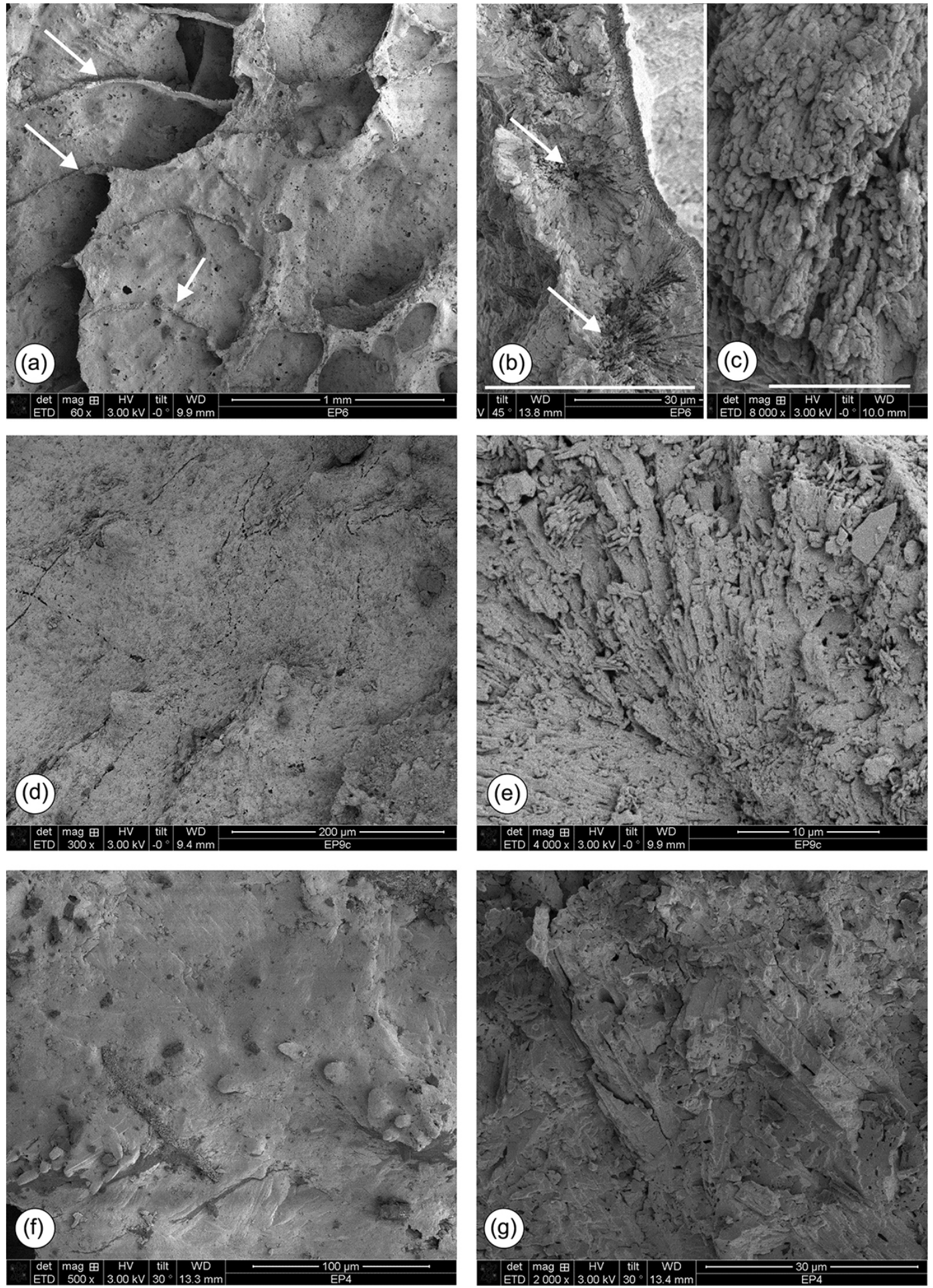

Figure 2. SEM view of septa and dissepiments. (a) Septal surface with traces of broken dissepiments. Septa and dissepiments are devoid of biogenic incrustations and inorganic cements (EP6). (b) Cross section of a dissepiment displaying radial fiber architecture of the sclerodermites. The centres of calcification exhibit minor dissolution. (c) Detail of a dissepiment showing polycrystalline aragonite fibers composed of granular crystallites (EP6). (d) Surface view of a septum. The septum is perforated by abundant near-surface, filamentous microborings but exhibits no secondary incrustations and/or cements (EP9c). (e) Cross section of dissepiment showing radial arrangement of bladed crystal fibers (EP9c). (f) Surface view of a septum with biogenic incrustation (EP4). (g) Sectional view of the coenosteum porosity infilled with densely packed fibers of bladed aragonite. Some channel porosity is present between fibers (EP4). This specimen was not used for density measurements. 


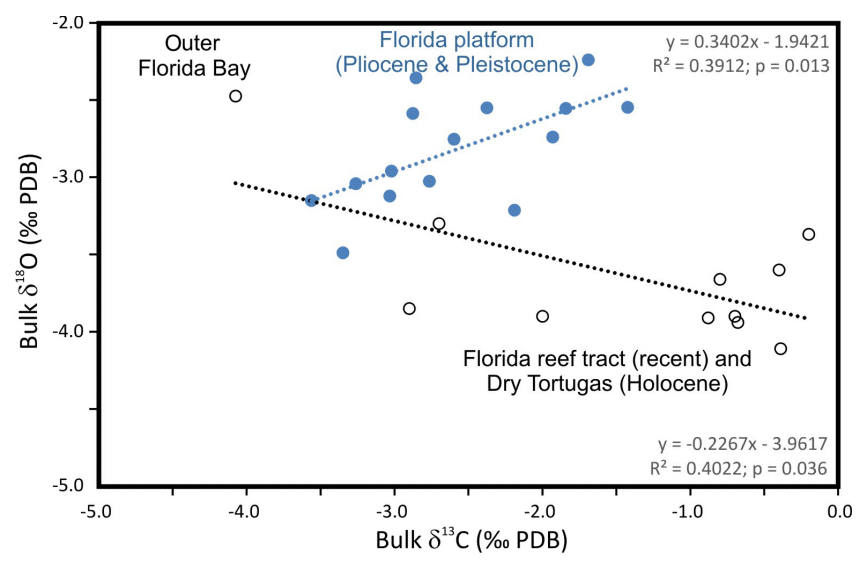

Figure 3. Bulk stable isotope values of Florida reef corals. Circles: recent and Holocene; Dots: Interglacial Pliocene and Pleistocene. Recent and Holocene data from literature (Leder et al., 1991, 1996; Smith, 2006; Swart et al., 1996).

we consider the skeletons to be in a mode of preservation suitable for measurements of stable isotope proxies and calcification rates.

\subsection{Stable isotope data and linear extension rates}

The bulk stable isotope compositions of the $\mathrm{z}$ corals studied were calculated as the arithmetic mean of all measurements in a given specimen. The bulk values range from -3.56 to $-1.42 \%$ o (mean $-2.59 \pm 0.65 \%$ ) in $\delta^{13} \mathrm{C}$ and -3.49 to $-2.04 \%$ (mean $-2.75 \pm 0.37 \%$ o $)$ in $\delta^{18} \mathrm{O}$ resulting in a significant positive correlation $\left(R^{2}=0.39 ; p=0.013\right.$; Fig. 3$)$.

All corals display cyclic variations in $\delta^{18} \mathrm{O}$ and in $\delta^{13} \mathrm{C}$, interpreted to reflect seasonal cycles of sea surface temperature (SST), seawater $\delta^{18} \mathrm{O}\left(\delta^{18} \mathrm{O}_{\mathrm{w}}\right)$, the ratio of symbiont photosynthesis vs. heterotrophic feeding, and $\delta^{13} \mathrm{C}$ of seawater DIC. The mean amplitude of the $\delta^{18} \mathrm{O}$ cycle ranges from 0.96 to $2.25 \%$ (mean $1.5 \pm 0.41 \%$; Table 2). The mean annual maximum and minimum $\delta^{18} \mathrm{O}$ values are $-1.87 \pm 0.60 \%$ (range -2.74 to $-0.85 \%$ ) and $-3.49 \pm 0.32 \%$ (range -4.03 to $-3.02 \%$ ), respectively.

For $\delta^{13} \mathrm{C}$, we present the bulk values of the $\mathrm{z}$ corals which range from -3.56 to $-1.42 \%$ with a mean of $-2.59 \pm 0.65 \%$ (Table 2). We do not present statistics for the seasonal amplitude of $\delta^{13} \mathrm{C}$ because the variation of $\delta^{18} \mathrm{O}$ and $\delta^{13} \mathrm{C}$ is not necessarily in phase within a year and no independent age model has been used for $\delta^{13} \mathrm{C}$. Phase relationships among the $\delta^{18} \mathrm{O}$ and $\delta^{13} \mathrm{C}$ cycles differ between individual coral colonies as expressed by the correlation of their $\delta^{18} \mathrm{O}$ and $\delta^{13} \mathrm{C}$ data. Three well-expressed patterns exist: positive correlation, no correlation, and negative correlation (Fig. 4, Table 2). Positive correlations denote spatially coincident negative and/or positive isotope values whereas negative correlations are the expression of coincident positive and negative peaks of the isotope cycles $\left(=180^{\circ}\right.$ phase shift). No correlation is less straight forward to interpret and has two possible underlying causes: (1) a phase shift between 0 and $180^{\circ}$ or, (2) the absence of any well expressed cyclic signal in $\delta^{13} \mathrm{C}$. Relationships of the coefficient of correlation from subannual $\delta^{18} \mathrm{O} / \delta^{13} \mathrm{C}$ values with skeletal $\delta^{18} \mathrm{O}$ values are noisy and barely significant; nonetheless, a significant positive correlation exists with mean annual $\delta^{18} \mathrm{O}\left(R^{2}=0.28 ; p=0.050\right)$ but not so with mean seasonality $\left(R^{2}=0.13 ; p=0.214\right)$ and mean peak summer values $\left(R^{2}=0.08 ; p=0.317\right)$, but to some degree with mean peak winter values $\left(R^{2}=0.22 ; p=0.087\right)$. All seasonally resolved coral records are shown in Fig. 4, and an overview of the main compositional trends is given in Table 2.

In the seasonally resolved data sets, a positive correlation exists between bulk $\delta^{18} \mathrm{O}$ and winter- $\delta^{18} \mathrm{O}\left(R^{2}=0.90\right.$; $p<0.001)$ and summer- $\delta^{18} \mathrm{O}\left(R^{2}=0.80 ; p<0.001\right)$, respectively, however, the slopes of the two relationships significantly differ and document large $\delta^{18} \mathrm{O}$-seasonality to coincide with more positive bulk $\delta^{18} \mathrm{O}$ and small $\delta^{18} \mathrm{O}$ seasonality to coincide with more negative bulk $\delta^{18} \mathrm{O}$ (equality of slopes can be rejected at $p<0.001$; Fig. 6). A positive relationship also exists between bulk $\delta^{13} \mathrm{C}$ and the means of peak seasonal $\delta^{18} \mathrm{O}\left(R^{2}=0.61 ; p=0.001\right.$ and $R^{2}=0.28 ; p=0.051$ ), but the slopes of the relationships remain indistinguishable (equality of slopes cannot be rejected at $p=0.78$ ), i.e. seasonality does not change with bulk $\delta^{13} \mathrm{C}$ (Fig. 6). Further, the mean of the maximum values in $\delta^{18} \mathrm{O}$ and mean seasonal $\delta^{18} \mathrm{O}$ contrast $\left(\Delta \delta^{18} \mathrm{O}\right)$ display a positive correlation $\left(R^{2}=0.76, p<0.001\right)$, whereas there is no such relationship among means of the minimum $\delta^{18} \mathrm{O}$ values and mean $\Delta \delta^{18} \mathrm{O}\left(R^{2}=0.22, p=0.069\right.$; Fig. 7). For the sake of simplicity in the following text, we use the terms mean summer for the mean of the minimum values and mean winter for the mean of the maximum values of $\delta^{18} \mathrm{O}$.

From this pattern we infer the following general nature of the $\delta^{18} \mathrm{O}$ and $\delta^{13} \mathrm{C}$ cycles: (1) low seasonality coincides with particularly negative bulk $\delta^{18} \mathrm{O}$ values, whereas bulk $\delta^{13} \mathrm{C}$ has no relationship with seasonality; (2) variability in the seasonality of the $\delta^{18} \mathrm{O}$ cycle $\left(\Delta \delta^{18} \mathrm{O}\right)$ is an effect of variations of the mean winter $\delta^{18} \mathrm{O}$ values only, whereas the mean summer $\delta^{18} \mathrm{O}$ values display little variation; (3) mean peak winter $\delta^{18} \mathrm{O}$ values are increasingly positive in parallel with the bulk $\delta^{18} \mathrm{O}$, and (4) the phase shift between the $\delta^{18} \mathrm{O}$ and $\delta^{13} \mathrm{C}$ cycles increases with more positive winter $\delta^{18} \mathrm{O}$ values of the $\delta^{18} \mathrm{O}$ cycles. (5) Bulk $\delta^{13} \mathrm{C}$ values are particularly negative in specimens displaying negative mean summer and winter $\delta^{18} \mathrm{O}$ (Fig. 6). These relationships imply a causative link between bulk $\delta^{18} \mathrm{O}, \Delta \delta^{18} \mathrm{O}$ and the phase relationship of $\delta^{13} \mathrm{C}$ and $\delta^{18} \mathrm{O}$.

Z-corals from one single sampling site or between sites do not exhibit any consistent distributional systematic of the three $\delta^{13} \mathrm{C} / \delta^{18} \mathrm{O}$ correlation patterns described above, i.e. all three patterns might be encountered at one single site and, therefore, no systematic distribution exists over geological time and inconsistent patterns over geological time are not 
(a)
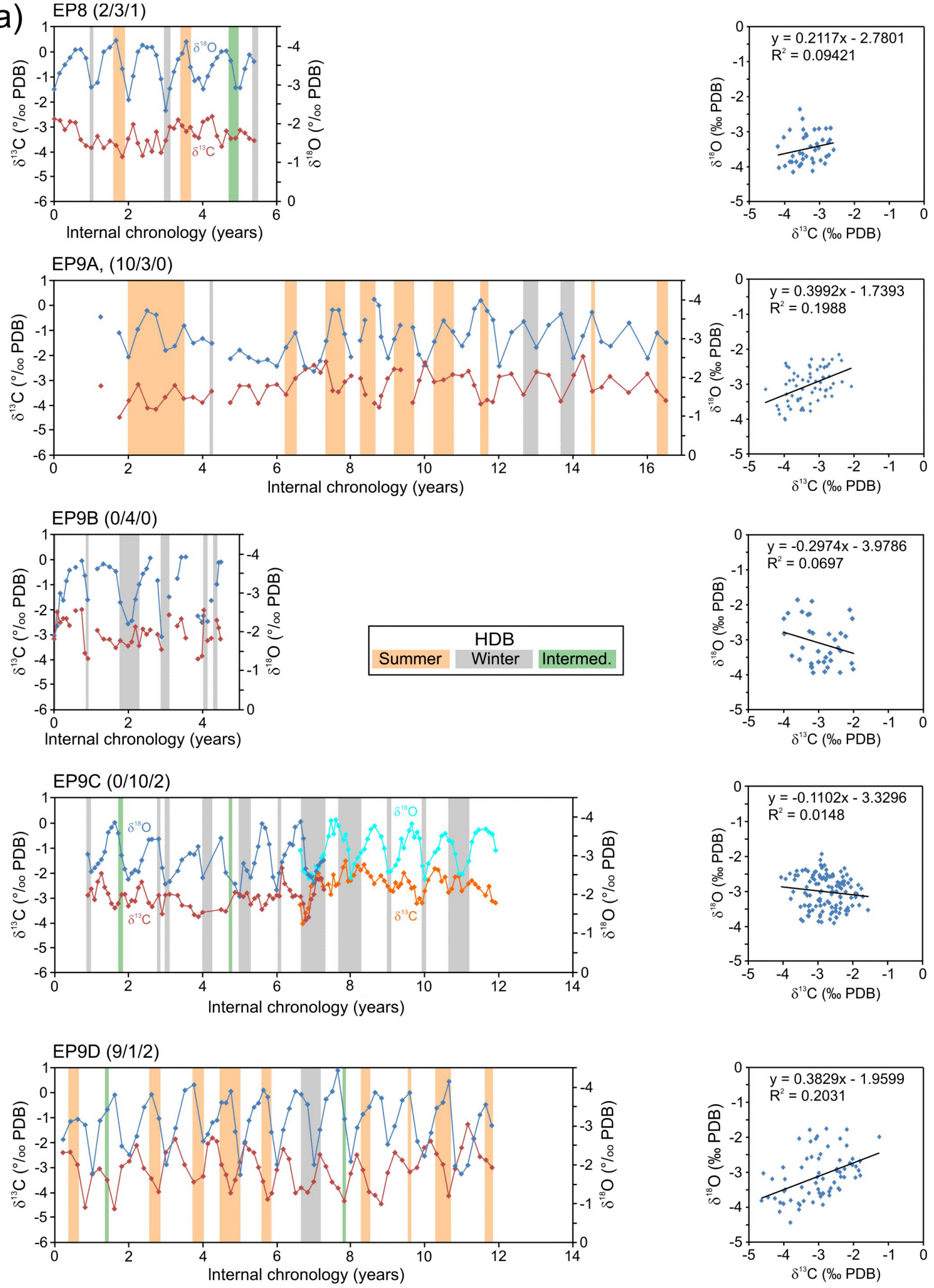

Figure 4. 

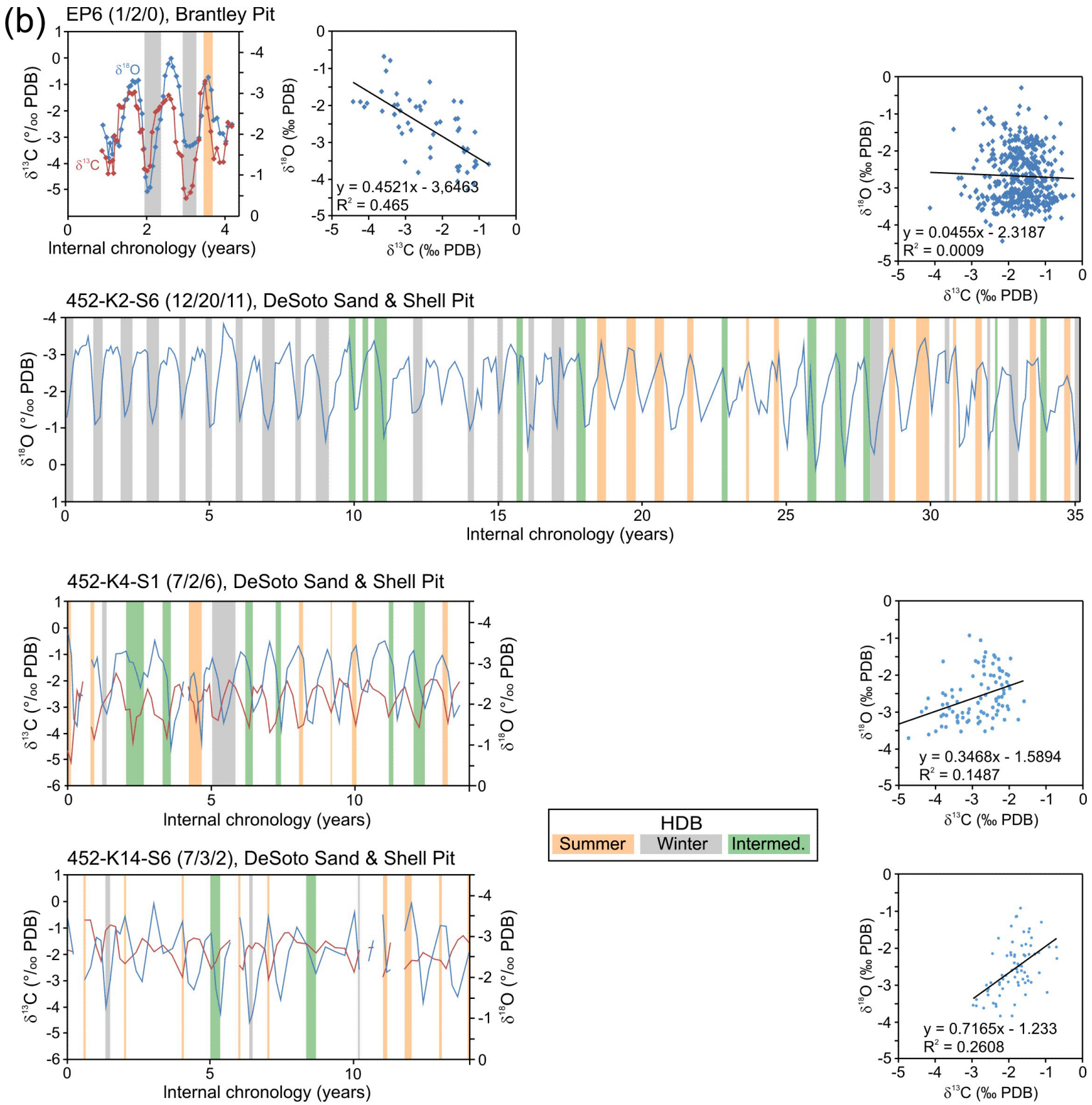

Figure 4. 

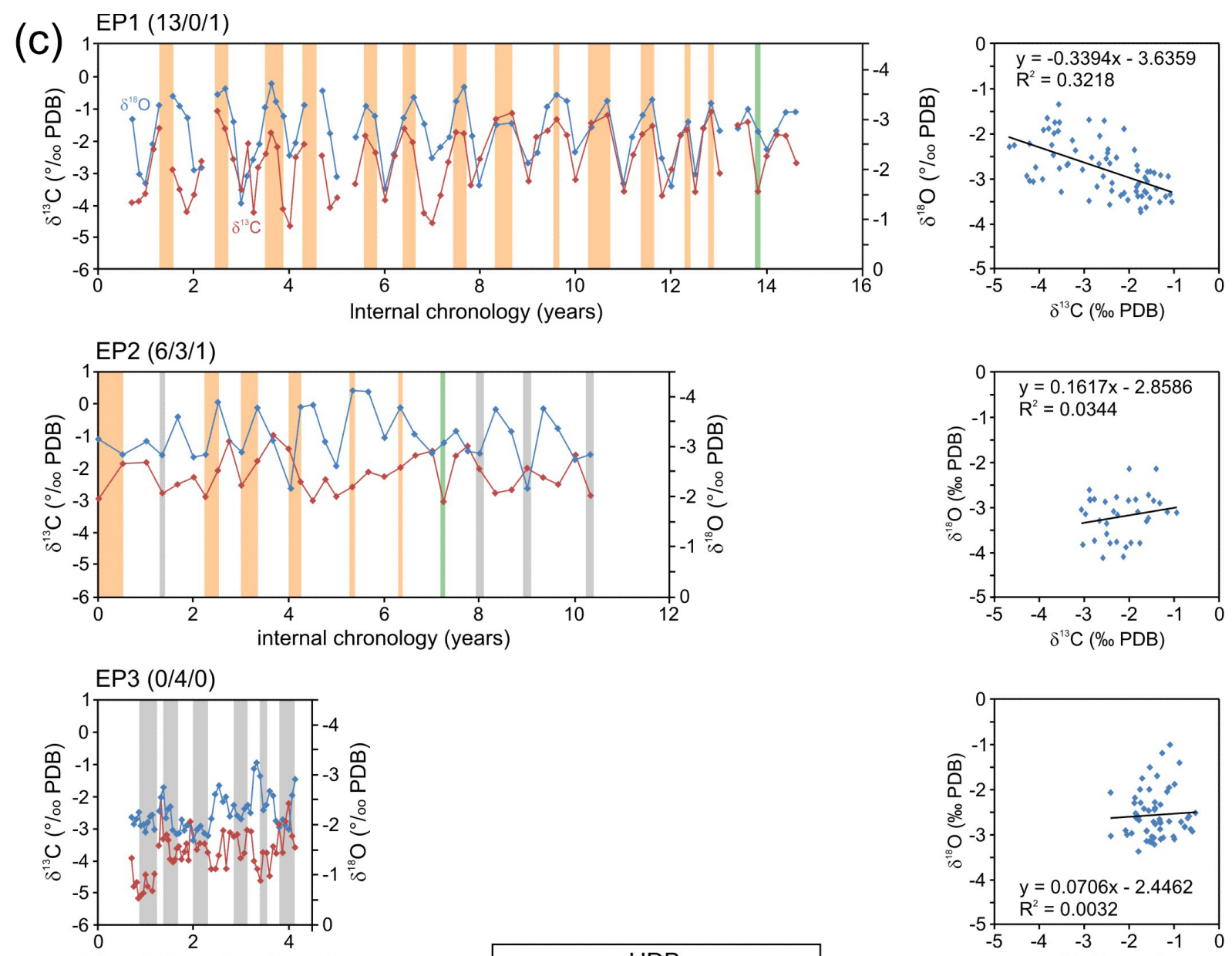

Internal chronology (years)
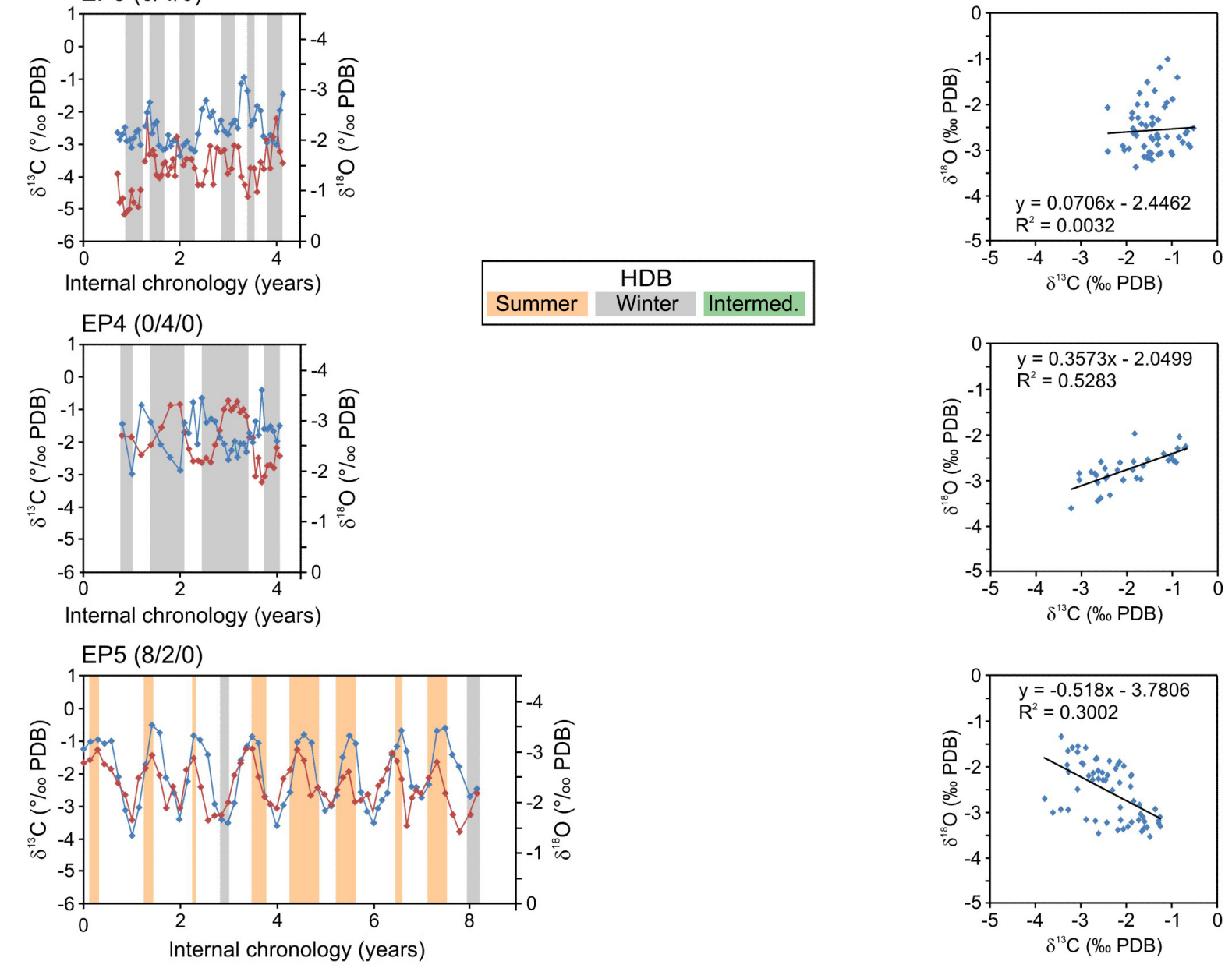

Figure 4. 

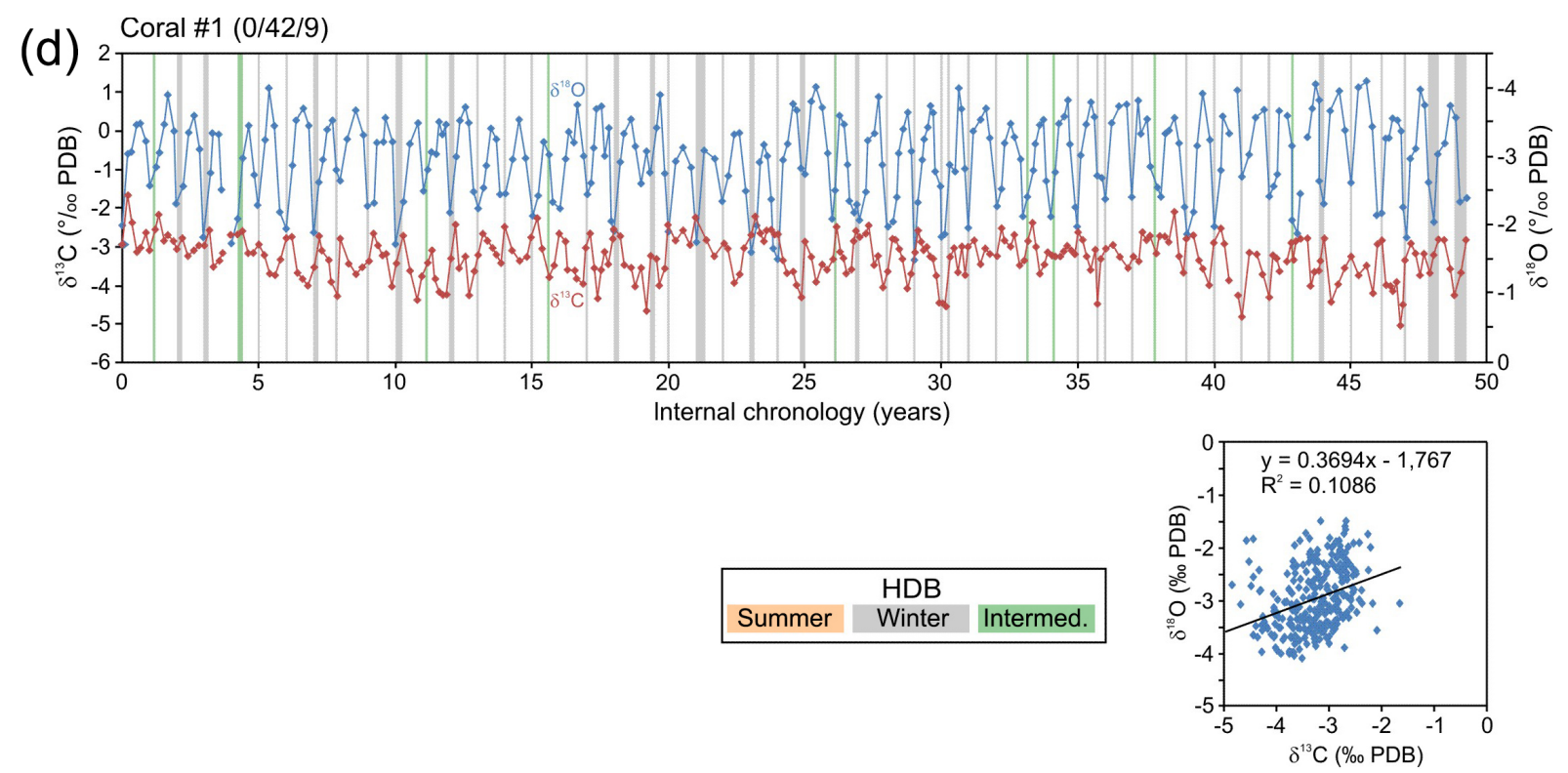

Figure 4. (a) Serial records of $\delta^{18} \mathrm{O}$ and $\delta^{13} \mathrm{C}$ in $\mathrm{z}$ corals from the Holey Land Member of the Bermont Formation (Palm Beach Aggregates, 1.2 Ma). Notice inverted scale of $\delta^{18} \mathrm{O}$. (b) Serial records of $\delta^{18} \mathrm{O}$ and $\delta^{13} \mathrm{C}$ in z corals from the Bee Branch Member of the Caloosahatchee Formation (1.8 Ma). Notice inverted scale of $\delta^{18} \mathrm{O}$. (c) Serial records of $\delta^{18} \mathrm{O}$ and $\delta^{13} \mathrm{C}$ in z corals from the Golden Gate Member of the Tamiami Formation (Mule Pen quarry, 2.5 Ma). Notice inverted scale of $\delta^{18} \mathrm{O}$. (d) Serial records of $\delta^{18} \mathrm{O}$ and $\delta^{13} \mathrm{C}$ in a coral from the Pinecrest Member of the Tamiami Formation (Quality Aggregates, 3.2 Ma; Roulier and Quinn, 1995). Notice inverted scale of $\delta^{18} \mathrm{O}$.

Table 2. Carbon and oxygen stable isotope composition (\%o vs. PDB) of z corals, Pliocene and Pleistocene, Florida, USA.

\begin{tabular}{|c|c|c|c|c|c|c|c|c|c|}
\hline Specimen & Taxon & $\begin{array}{c}\text { Number of } \\
\text { analyses }(n)\end{array}$ & $\begin{array}{l}\text { Length of record } \\
\left(\delta^{18} \mathrm{O} \text { years }\right)\end{array}$ & $\begin{array}{r}\text { Bulk } \delta^{13} \mathrm{C} \\
( \pm 1 \sigma)\end{array}$ & $\begin{array}{l}\text { Mean annual } \\
\delta^{18} \mathrm{O}( \pm 1 \sigma)\end{array}$ & $\begin{array}{r}\text { Correlation } \\
\text { coefficient }(r) \\
\text { of } \delta^{13} \mathrm{C} / \delta^{18} \mathrm{O}\end{array}$ & $\begin{array}{r}\text { Average annual } \\
\text { maximum } \\
\delta^{18} \mathrm{O}( \pm 1 \sigma)\end{array}$ & $\begin{array}{r}\text { Average annual } \\
\text { minimum } \\
\delta^{18} \mathrm{O}( \pm 1 \sigma)\end{array}$ & $\begin{array}{l}\text { Mean seasonal } \\
\Delta \delta^{18} \mathrm{O}( \pm 1 \sigma)\end{array}$ \\
\hline EP1-S2 & Solenastrea & 76 & 16 & $-2.60 \pm 0.99$ & $-2.69 \pm 0.22$ & -0.57 & $-1.95 \pm 0.39$ & $-3.41 \pm 0.23$ & $1.39 \pm 0.48$ \\
\hline EP2-S2 & Orbicella & 34 & 10 & $-2.19 \pm 0.58$ & $-3.21 \pm 0.19$ & 0.19 & $-2.71 \pm 0.27$ & $-3.74 \pm 0.29$ & $0.99 \pm 0.43$ \\
\hline EP3 & Porites & 58 & 4 & $-1.42 \pm 0.43$ & $-2.46 \pm 0.43$ & 0.06 & $-1.50 \pm 0.42$ & $-3.05 \pm 0.28$ & $1.60 \pm 0.20$ \\
\hline EP4-S2 & Solenastrea & 35 & 4 & $-1.93 \pm 0.76$ & $-2.62 \pm 0.19$ & 0.73 & $-2.27 \pm 0.30$ & $-3.45 \pm 0.13$ & $1.15 \pm 0.24$ \\
\hline EP5-S2 & Solenastrea & 62 & 8 & $-2.38 \pm 0.66$ & $-2.60 \pm 0.23$ & -0.55 & $-1.67 \pm 0.27$ & $-3.35 \pm 0.09$ & $1.67 \pm 0.22$ \\
\hline EP6-S2 & Solenastrea & 54 & 4 & $-2.86 \pm 1.18$ & $-2.26 \pm 0.25$ & -0.68 & $-1.30 \pm 0.55$ & $-3.51 \pm 0.29$ & $2.25 \pm 0.86$ \\
\hline EP8 & Solenastrea & 42 & 5 & $-3.35 \pm 0.43$ & $-3.50 \pm 0.10$ & 0.21 & $-2.74 \pm 0.15$ & $-4.03 \pm 0.15$ & $1.28 \pm 0.33$ \\
\hline EP9A & Solenastrea & 68 & 15 & $-3.26 \pm 0.54$ & $-3.02 \pm 0.26$ & 0.45 & $-2.61 \pm 0.35$ & $-3.55 \pm 0.27$ & $0.96 \pm 0.31$ \\
\hline ЕР9B & Orbicella & 48 & 4 & $-3.02 \pm 0.72$ & $-2.93 \pm 0.33$ & -0.26 & $-2.14 \pm 0.39$ & $-3.86 \pm 0.08$ & $1.57 \pm 0.43$ \\
\hline EP9C & Solenastrea & 135 & 12 & $-2.76 \pm 0.52$ & $-2.98 \pm 0.25$ & -0.12 & $-2.35 \pm 0.18$ & $-3.60 \pm 0.29$ & $1.25 \pm 0.33$ \\
\hline EP9D & Solenastrea & 69 & 12 & $-3.03 \pm 0.77$ & $-3.11 \pm 0.23$ & 0.45 & $-2.12 \pm 0.29$ & $-3.91 \pm 0.30$ & $1.79 \pm 0.36$ \\
\hline Coral \# $1^{* *}$ & Solenastrea & 286 & 49 & $-3.56 \pm 0.57$ & $-3.19 \pm 0.19$ & 0.33 & $-2.22 \pm 0.27$ & $-3.89 \pm 0.21$ & $1.68 \pm 0.26$ \\
\hline $452-\mathrm{K} 1^{*}$ & Solenastrea & 468 & 35 & $-1.69 \pm 0.55$ & $-2.23 \pm 0.30$ & -0.03 & $-1.02 \pm 0.46$ & $-3.10 \pm 0.28$ & $2.06 \pm 0.50$ \\
\hline 452-K4-S1 & Solenastrea & 99 & 14 & $-2.88 \pm 0.72$ & $-2.59 \pm 0.19$ & 0.15 & $-1.61 \pm 0.42$ & $-3.29 \pm 0.28$ & $1.69 \pm 0.48$ \\
\hline 452-K14-S6 & Solenastrea & 77 & 14 & $-1.84 \pm 0.50$ & $-2.58 \pm 0.24$ & 0.26 & $-1.95 \pm 0.76$ & $-3.36 \pm 0.35$ & $1.73 \pm 0.93$ \\
\hline
\end{tabular}

* From Böcker (2014). ** From Roulier and Quinn (1995).

the effects of potential shortcomings of stratigraphic classifications.

\subsection{Calcification}

In positive prints of radiographs all corals display well expressed alternations of light and dark bands arranged parallel to the surface of the corallum (the colonial skeleton) and normal to the direction of maximum growth of the corallites (Fig. 8). No specimens without density bands, or specimens displaying a patchy concentration of zones with high or low density, except for the expression of large borings by bivalves, were documented in the material recovered (Fig. 8).

These alternating bands of high and low density are commonly present in massive heads of $\mathrm{z}$ corals, and referred to as "density bands" because the changes in grey tones of the radiographs reflect density variations of the coral skeleton (Knutson et al., 1972; Lough and Cooper, 2011). The alternating density bands without any indication of patchy or blurred density variations is an indication of the good preservation of the original skeletal density variation without any secondary modifications through diagenesis. In this study, 

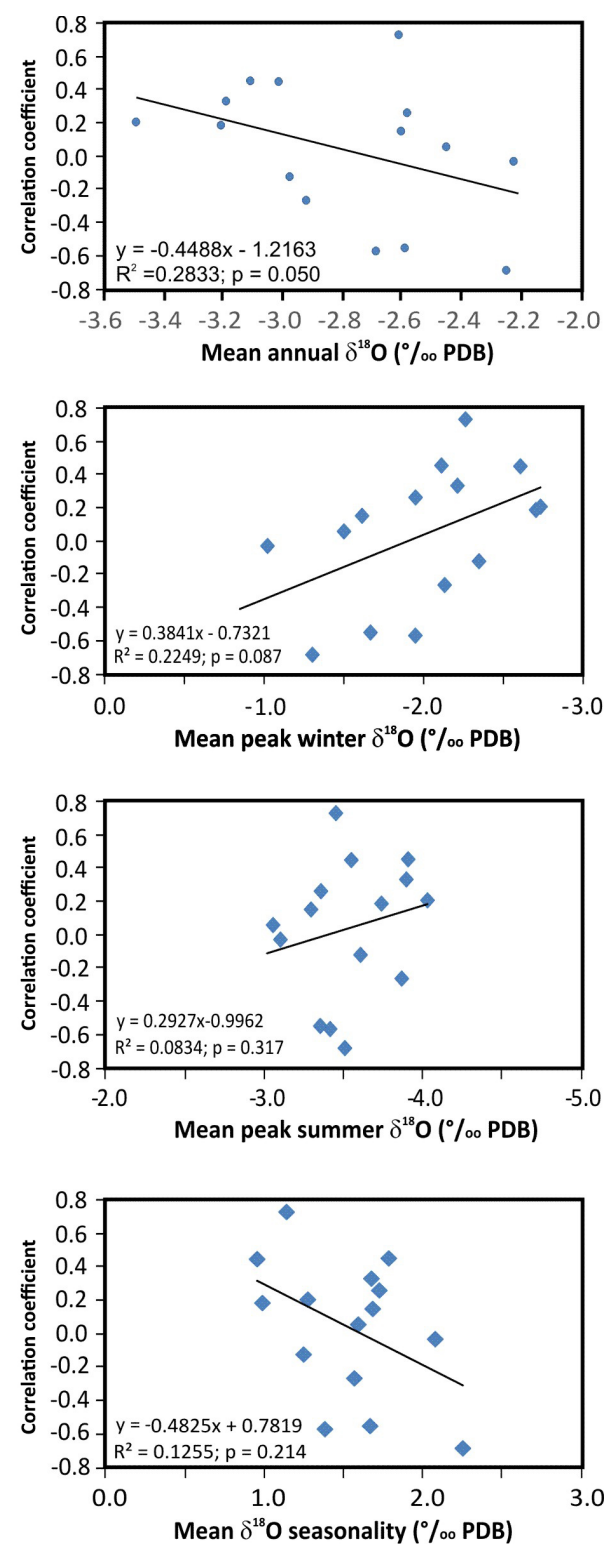

Figure 5. Relationships of skeletal $\delta^{18} \mathrm{O}$ with the coefficient of correlation between subannual $\delta^{18} \mathrm{O}$ and $\delta^{13} \mathrm{C}$ values.
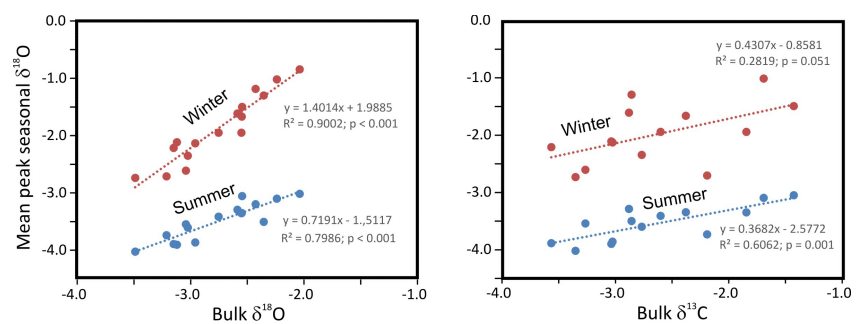

Figure 6. Bulk stable isotope composition $\left(\delta^{13} \mathrm{C}, \delta^{18} \mathrm{O}\right)$ compared to the averages of the minimum and maximum values of $\delta^{18} \mathrm{O}$ interpreted to represent maximum summer and winter, respectively.
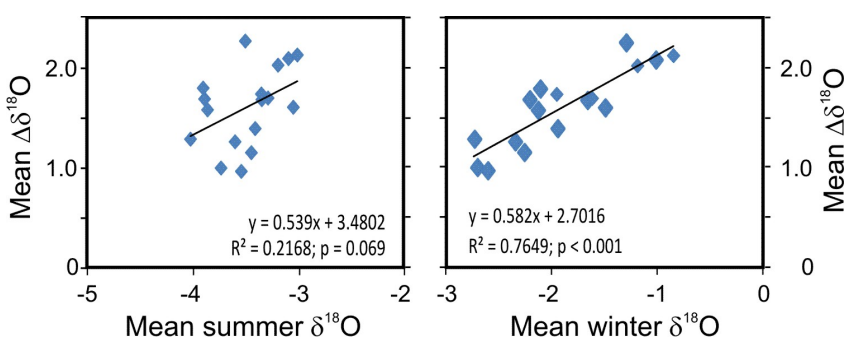

Figure 7. Mean seasonal contrast of skeletal $\delta^{18} \mathrm{O}\left(\right.$ mean $\left.\Delta \delta^{18} \mathrm{O}\right)$ compared to the means of maximum summer and winter skeletal $\delta^{18} \mathrm{O}$.

however, we do not use the density bands for calibrating internal chronologies and calculating linear extension rates but use the oxygen isotope cycles instead (Fig. 8). Skeletal linear extension rates were established from $\delta^{18} \mathrm{O}$ cyclicity, and they range from 0.16 to $0.83 \mathrm{~cm} \mathrm{yr}^{-1}$, with a mean of $0.49 \pm 0.22 \mathrm{~cm} \mathrm{yr}^{-1}$ (Table 3). More details on the determination of linear extension rates and relationships with the $\delta^{18} \mathrm{O}$ cycles are given in the "methods" section.

With regard to the $\delta^{18} \mathrm{O}$ and $\delta^{13} \mathrm{C}$ cycles, no consistent relationship was found with the density bands. Rather, within any given fossil sample, maximum skeletal density either coincides with the maximum or minimum $\delta^{18} \mathrm{O}$ values, but specimens with an irregular timing of the HDB with respect to the $\delta^{18} \mathrm{O}$ cycle are also present. We express the relationship of the density bands and $\delta^{18} \mathrm{O}$ cycles by the winter HDB portion (Fig. 9, Table 2). The winter HDB portion was calculated as the ratio of the number of winter HDBs and the total number of HDBs in a stable isotope record; the summer HDB and intermediate-HDB portions were calculated respectively. In one of the two long records (452K1) the overall timing of the HDBs is irregular with a low summer HDB portion, although within short segments of a few years of duration, the timing of the HDBs is uniform and related either to maximum, minimum or intermediate $\delta^{18} \mathrm{O}$ values (Fig. 4, Table 2). Because the corallites sampled were selected according to their orientation parallel to the surface of the coral slabs, asynchronies between stable isotope cycles and density bands are not an artifact of distortions in our X-ray images (Le Tissier et al., 1994). With regard to the distribution of the patterns on the scale of a reef (geological outcrop) or geological time (time slice), we do not observe any consistent pattern; rather all types of density band $/{ }^{18} \mathrm{O}$ relationships were recovered at one single site or time slice.

Quantitative measurements of density were performed in transects arranged parallel to the corallites and transects of the isotope measurements. Bulk density, calculated as the means of all individual measurements along a transect is highly variable among corals with a range from 0.6 to $1.2 \mathrm{~g} \mathrm{~cm}^{-3}$ (mean $0.9 \pm 0.2 \mathrm{~g} \mathrm{~cm}^{-3}$ ). Bulk density and extension rate display a significant negative correlation 
Table 3. Mean annual skeletal extension rate $( \pm 1 \sigma)$, bulk density $( \pm 1 \sigma)$, and calcification rate of massive corals (Solenastrea, Orbicella, Porites) from the Plio-/Pleistocene of Florida. Minimum $\delta^{18} \mathrm{O}$ values reflecting high water temperature and/or positive water balance are being referred to as "summer", maximum $\delta^{18} \mathrm{O}$ values cool temperatures and/or negative water balance are referred to here as "winter". Timing of the high density band (HDB) relative to the $\delta^{18} \mathrm{O}$ cycle.

\begin{tabular}{|c|c|c|c|c|c|}
\hline Specimen & Taxon & $\begin{array}{r}\text { Mean extension } \\
\text { rate }\left(\mathrm{cm} \mathrm{yr}^{-1}\right)\end{array}$ & $\begin{array}{l}\text { Bulk density } \\
\qquad\left(\mathrm{g} \mathrm{cm}^{-3}\right)\end{array}$ & $\begin{array}{l}\text { Calcification rate } \\
\left(\mathrm{g} \mathrm{cm}^{-2} \mathrm{yr}^{-1}\right)\end{array}$ & $\begin{array}{l}\text { Timing of HDB } \\
\text { (summer/winter/ } \\
\text { intermediate) }\end{array}$ \\
\hline EP1-S2 & Solenastrea sp. & $0.28 \pm 0.08$ & $1.22 \pm 0.17$ & 0.34 & $10 / 0 / 1$ \\
\hline EP2-S2 & Orbicella annularis & $0.16 \pm 0.03$ & $1.14 \pm 0.25$ & 0.18 & $6 / 3 / 1$ \\
\hline EP3 & Porites sp. & $0.86 \pm 0.22$ & $0.60 \pm 0.12$ & 0.52 & $0 / 4 / 0$ \\
\hline EP4-S2 & Solenastrea sp. & $0.45 \pm 0.28$ & n.a. & n.a. & $0 / 4 / 0$ \\
\hline EP5-S2 & Solenastrea sp. & $0.37 \pm 0.06$ & $1.22 \pm 0.21$ & 0.45 & $8 / 2 / 0$ \\
\hline EP6-S2 & Solenastrea sp. & $0.83 \pm 0.21$ & $0.55 \pm 0.06$ & 0.46 & $1 / 2 / 0$ \\
\hline EP8 & Solenastrea sp. & $0.38 \pm 0.05$ & $1.16 \pm 0.12$ & 0.44 & $2 / 3 / 1$ \\
\hline EP9A & Solenastrea sp. & $0.22 \pm 0.08$ & $0.94 \pm 0.16$ & 0.21 & $10 / 3 / 0$ \\
\hline ЕР9B & Orbicella annularis & $0.64 \pm 0.25$ & $0.76 \pm 0.09$ & 0.48 & $0 / 4 / 0$ \\
\hline EP9C & Solenastrea sp. & $0.58 \pm 0.11$ & $0.73 \pm 0.08$ & 0.43 & $0 / 10 / 2$ \\
\hline EP9D & Solenastrea sp. & $0.29 \pm 0.05$ & $1.00 \pm 0.18$ & 0.29 & $9 / 1 / 2$ \\
\hline Coral $\# 1^{\mathrm{a}}$ & Solenastrea bournoni & $0.41 \pm 0.09$ & n.a. & n.a. & $0 / 42 / 9$ \\
\hline $452 \mathrm{~K} 1$ total & Solenastrea sp. & $0.63 \pm 0.16$ & $0.73 \pm 0.90$ & $\begin{array}{l}0.4 \text { to } 0.5 \\
(\varnothing=0.45)\end{array}$ & $10 / 20 / 11$ \\
\hline 452 , lower segment & Solenastrea sp & $0.71 \pm 0.14$ & 0.70 & 0.50 & \\
\hline 452 , upper segment & Solenastrea sp. & $0.55 \pm 0.17$ & 0.56 & 0.31 & \\
\hline $452-\mathrm{K} 4-\mathrm{S} 1$ & Solenastrea sp. & 0.35 & $0.93 \pm 0.14$ & 0.33 & $7 / 2 / 6$ \\
\hline 452-K14-S6 & Solenastrea sp. & 0.26 & $1.52 \pm 0.25$ & 0.40 & $7 / 3 / 2$ \\
\hline $509 \mathrm{~A}^{\mathrm{b}}$ & Solenastrea sp. & $0.36 \pm 0.15(0.22)$ & n.a. & n.a. & n.a. \\
\hline
\end{tabular}

${ }^{\mathrm{a}}$ No data on bulk density and extension rates available (Roulier and Quinn, 1995). ${ }^{\mathrm{b}}$ Extension rate from spacing of density bands, in parentheses from $\delta^{18} \mathrm{O}$ data (Böcker, 2014).

$\left(R^{2}=0.42, p=0.003\right)$. Over time, no significant changes in density were recorded $\left(R^{2}=0.04, p=0.438\right)$.

\section{Discussion}

\subsection{Interpretation of the stable isotope systematics}

Linear positive correlations of paired $\delta^{13} \mathrm{C} / \delta^{18} \mathrm{O}$ data are common in skeletal carbonates and have been shown to be related to kinetic isotope effects responding to variable rates of skeletogenesis (McConnaughey, 1989). Kinetic behaviour involves simultaneous depletion of $\delta^{13} \mathrm{C}$ and $\delta^{18} \mathrm{O}$ with respect to isotopic equilibrium which results in a positive correlation of $\delta^{13} \mathrm{C} / \delta^{18} \mathrm{O}$ along a straight line between equilibrium and values 10 to $15 \%$ more negative in $\delta^{13} \mathrm{C}$ and $4 \%$ o in $\delta^{18} \mathrm{O}$ than expected from equilibrium precipitation (McConnaughey, 1989). The positive correlation of the paired bulk stable isotope values from the fossil Florida $\mathrm{z}$ corals, however, is not a kinetic signature because a positive correlation of $\delta^{13} \mathrm{C}$ and $\delta^{18} \mathrm{O}$ is not necessarily present in the seasonal data which do show all transitions from positive correlation to no correlation and negative correlation among the various coral specimens. Furthermore, average linear skeletal extension rates of the Florida fossils are rather high $(n=15$; mean $=0.49 \pm 0.22 \mathrm{~cm} \mathrm{yr}^{-1}$; Table 3 ) which rules out vari- ability of the serial stable isotope data presented in this study having no environmental meaning (McConnaughey, 1989). The positive trend of bulk $\delta^{13} \mathrm{C} / \delta^{18} \mathrm{O}$ as recorded by the Pliocene and Pleistocene $\mathrm{z}$ corals, therefore, represents a distinct environmental proxy record (Fig. 3). The pattern may have at least two different underlying causes: (1) a proximity trend reflecting a continuum of settings from freshwater-influenced environments with the most negative $\delta^{18} \mathrm{O}$ and $\delta^{13} \mathrm{C}$ values towards near-shore-restricted, and finally open, well mixed environments with the most positive stable isotope signatures (Andrews, 1991; Joachimski, 1994), or (2) variable upwelling of cool, nutrient enriched subsurface water masses. According to scenario (1), corals with the most positive $\delta^{13} \mathrm{C}$ and $\delta^{18} \mathrm{O}$ signatures may be interpreted as the most marine and the least affected by environmental restriction and hinterland effects. Such a trend of positive correlation between bulk oxygen and carbon stable isotope values of the fossil $\mathrm{z}$ corals is not, however, present in data from modern and Holocene $\mathrm{z}$ corals from Florida Bay, Florida Reef Tract, and Dry Tortugas (Figs. 1, 3). In these corals, bulk stable isotope values display substantially larger variation than in the Pliocene and Pleistocene fossils, and range from -4.07 to $-0.20 \%$ in $\delta^{13} \mathrm{C}(n=11$; mean $-1.53 \pm 1.31 \%$ ) and $\delta^{18} \mathrm{O}$ from -4.11 to $-2.47 \%$ (mean $-3.64+0.46 \%$ ) with a negative correlation $\left(R^{2}=0.40\right.$; 

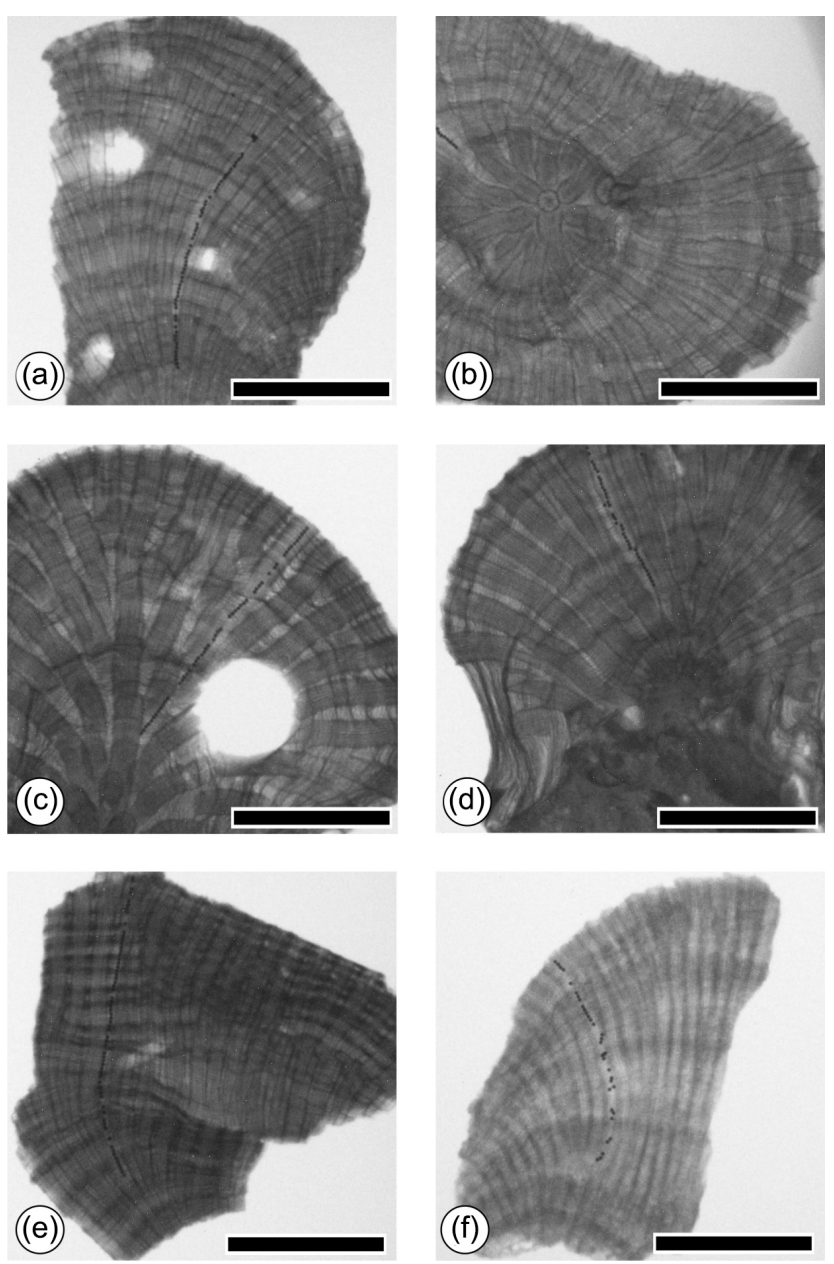

Figure 8. Digital radiographs (positive prints) of fossil z corals showing density bands (Pliocene and Pleistocene) of Florida. Circular white spots represent open voids of bivalves borings. (a) Solenastrea sp. (EP9D). (b) Solenastrea sp. (EP9B). (c) Solenastrea sp. (EP9A). (d) Orbicella encrusted on a hardground (EP 8). (e) Solenastrea sp., white patch within the centre is from bioerosional cavity. (g) Solenastrea sp. (EP1) (f) Porites sp. (EP3). For better contrast, steel balls $(\varnothing=0.5 \mathrm{~mm})$ mark sampling transect. Scale bar $2 \mathrm{~cm}$, all radiographs reproduced to same size.

$p=0.036$; Fig. 3). The negative correlation, however, is an artifact of the set of literature data available to us and is lost if the coral data from Florida Bay and from the reef systems were considered separately (reef tract only: $n=10$; $R^{2}=0.02 ; p=0.668$ ). In the recent corals, the negative $\delta^{13} \mathrm{C}$ value derives from a single Florida Bay coral and records the low $\delta^{13} \mathrm{C}$ of the DIC in the bay waters formed by oxidative decay of organic matter and/or vegetative respiration (Halley and Roulier, 1999). In the fully open-marine settings of the reef tract positive skeletal $\delta^{13} \mathrm{C}$ reflects the marine carbon source of the DIC modified by metabolic effects. There, spatially variable skeletal $\delta^{13} \mathrm{C}$ records also derive from bay waters leaving the bay through passes in the Florida Keys where they mix with waters of the reef tract (Swart et al., 1996; Figs. 1, 3). In contrast, the $\delta^{18} \mathrm{O}$ values from $\mathrm{z}$ corals are essentially identical among reef sites along the presentday reef system and are predominantly controlled by SST effects with minor modifications by $\delta^{18} \mathrm{O}_{\mathrm{w}}$ (Leder et al., 1996; Smith, 2006). Skeletal $\delta^{18} \mathrm{O}$ values in Florida Bay are the most positive and reflect a high temperature signal to be overcompensated by the counteracting effects of evaporation in conjunction with influx of pre-evaporated freshwaters from adjacent swamps (Swart et al., 1996). For these reasons, the modern Florida model is likely not a good analogue for understanding the middle Pliocene to early Pleistocene records. This inference has also been made from the highly diverse Plio-Pleistocene reefs in south-west Florida (Meeder, 1979). In contrast, in the upwelling scenario (scenario 2) increasingly positive $\delta^{18} \mathrm{O}$ reflects surface water cooling in response to upwelling of cool nutrient-rich subsurface waters, while concomitant increasingly positive skeletal $\delta^{13} \mathrm{C}$ documents enhanced organic productivity (Berger and Vincent, 1986). Below, we will discuss the significance of the $\delta^{18} \mathrm{O}$ cycles for a plausible identification of the mechanisms behind the stable isotope record.

\subsection{Significance of the $\delta^{18} \mathrm{O}$ cycles}

The annual $\delta^{18} \mathrm{O}$ cycle is typically represented by seven samples, however, the resolution ranges from 2 to 21 samples per cycle $\left(n=185\right.$; mean $7.0 \pm 3.3$ samples cycle $\left.{ }^{-1}\right)$. Irrespective of the number of samples over a cycle, we consider the cycles to represent a seasonal signal which is used for defining the internal age models of the corals and for calculating annual linear extension rates (Table 3). Although there is little doubt the $\delta^{18} \mathrm{O}$ cycles reflect seasonality, sampling resolution within a year has been suggested to have a measurable effect on the amount of reconstructed seasonality (Leder et al., 1996). Earlier work on fossil corals has suggested a minimum of four samples in a year to be sufficient to resolve the seasonal cycle in geological data (Brachert et al., 2006b). For this reason, we consider our records a useful approximation to palaeoseasonality during the late Neogene.

Mean summer $\delta^{18} \mathrm{O}$ values of the fossils display little variation around their mean, whereas mean winter values display high variability and a strong link with mean $\Delta \delta^{18} \mathrm{O}$ variability (Fig. 7). For this reason, variability of $\Delta \delta^{18} \mathrm{O}$ is a function of variable winter values. For evaluating the question whether variability of winter $\delta^{18} \mathrm{O}$ values is a temperature or seawater effect, we use the bulk $\delta^{13} \mathrm{C}$ data. Bulk $\delta^{13} \mathrm{C}$ shows no relationship with $\Delta \delta^{18} \mathrm{O}$, i.e. the amount of variation in $\Delta \delta^{18} \mathrm{O}$ is not related with seasonal changes of the isotopic composition of the DIC as might occur through freshwater discharge or upwelling (Fig. 6). For this reason, significant subannual variations in $\delta^{18} \mathrm{O}_{\mathrm{w}}$ are not very plausible as an explanation for the observed variable seasonality which is rather controlled by fluctuations of the winter temperature. 

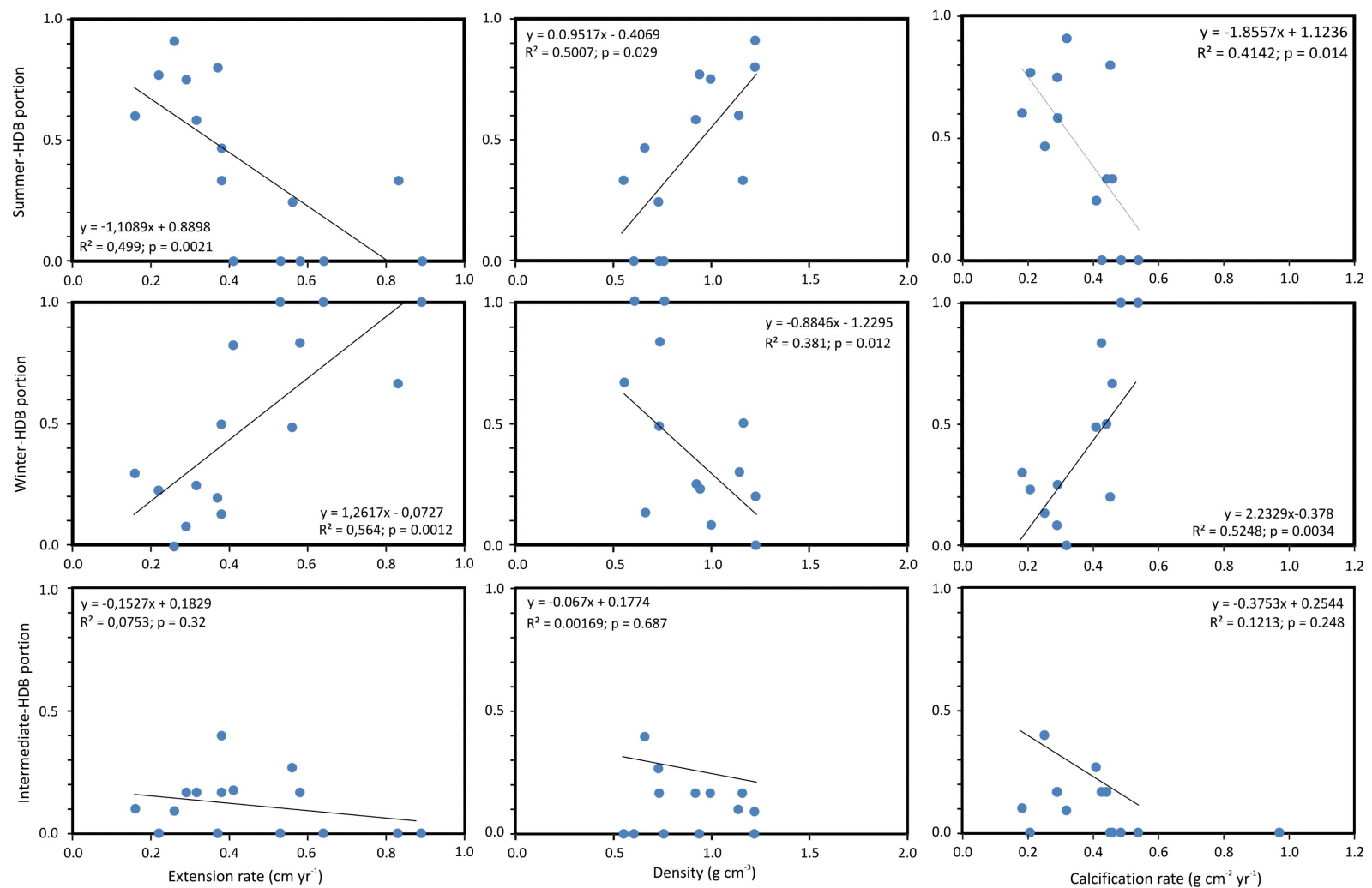

Figure 9. Relationship of annual extension rate, density and calcification rate with the timing of density banding in Pliocene and Pleistocene $\mathrm{z}$ corals from southern Florida (USA).

\subsection{Paleotemperatures}

For quantitative temperature reconstructions, the isotope composition of the ambient water itself plays a critical role. Because the oxygen isotope composition of the palaeoseawater is not known, we use the modern seawater composition at the Florida reef tract $\left(\delta^{18} \mathrm{O}_{\mathrm{w}}=1.1 \%\right.$; Leder et al., 1996) as a baseline for our reconstructions and for eventually making inferences about palaeoseawater $\delta^{18} \mathrm{O}_{\mathrm{w}}$ and the extent of freshwater discharges or evaporation. For our estimates we further assume all corals to have lived within the same waterdepth window and type of environment. Following this approach, the mean annual temperature averaged over all coral specimens $(n=15)$ was $22.6 \pm 1.9^{\circ} \mathrm{C}$ (range 19.5 to $26.0^{\circ} \mathrm{C}$ ) with an average mean seasonality of $7.2 \pm 1.9^{\circ} \mathrm{C}$ (range 4.3 to $10.2^{\circ} \mathrm{C}$ ). The latter reconstruction is surprisingly similar to modern instrumental seasonality of 7 to $9^{\circ} \mathrm{C}$ along the reef tract (Leder et al., 1996; Smith, 2006), but the reconstructed mean annual SST is below present-day's annual mean temperature of $27^{\circ} \mathrm{C}$ recorded at Looe Key (Smith, 2006) and $\sim 25^{\circ} \mathrm{C}$ along the south-western Florida coast (Fort Myers). In contrast, middle Pliocene to early Pleistocene interglacial temperatures in the western Atlantic warm pool were $\sim 2{ }^{\circ} \mathrm{C}$ above present values (O'Brien et al., 2014). For this reason, changes in global interglacial seawater $\delta^{18} \mathrm{O}_{\mathrm{w}}$ and the hydro- logical balance of the Florida peninsula must be taken into account for interglacials of the late Neogene (Brachert et al., 2014). In order to resolve Pliocene-Pleistocene interglacial SSTs $2{ }^{\circ} \mathrm{C}$ above present, we infer values of local $\delta^{18} \mathrm{O}_{\mathrm{w}}$ with a range between 1.9 to $2.9 \%$ on the basis of the temperature equation of Leder et al. (1996), although middle Pliocene to early Pleistocene global interglacial seawater $\delta^{18} \mathrm{O}_{\mathrm{w}}$ was similar to the present day, or even more negative (Zachos et al., 2001). Substantially more negative water values for the peninsula of $\delta^{18} \mathrm{O}_{\mathrm{w}}=1.0 \%$ o have been inferred by modelling Pliocene conditions (Williams et al., 2009).

According to this line of reasoning, evaporation should have been an essential driver of Pliocene and Pleistocene bulk skeletal $\delta^{18} \mathrm{O}$, and the $\mathrm{z}$ corals with the most positive bulk $\delta^{18} \mathrm{O}$ values being similar in magnitude to the recent Florida Bay coral have an evaporative signature in $\delta^{18} \mathrm{O}$. These corals, however, according to the positive relationship of paired bulk $\delta^{13} \mathrm{C} / \delta^{18} \mathrm{O}$ values, have the most open-marine $\delta^{13} \mathrm{C}$ signature, incompatible with concomitant maximum evaporation archived in skeletal $\delta^{18} \mathrm{O}$. We suggest, therefore, rejecting scenario (1) with evaporation having a strong imprint in $\delta^{18} \mathrm{O}$ signatures in favour of an alternate scenario (2) involving upwelling of cool and nutrient-rich waters peripheral to the Florida carbonate platform causing positive 


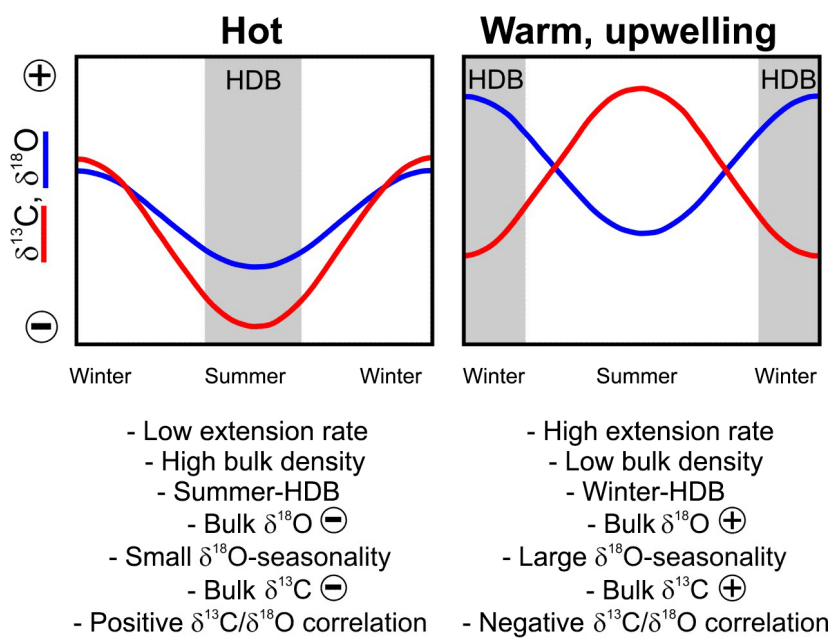

Figure 10. Schematic of endmember relationships of stable isotope data with the patterns of calcification and the timing of the HDB in middle Pliocene to early Pleistocene $\mathrm{z}$ corals from south-western Florida.

bulk $\delta^{13} \mathrm{C}$ signatures and lower than expected water temperatures.

\subsection{Relationships between stable isotope signatures and calcification systematics}

The couplets of light and dark bands visible in radiographs orientated parallel to the individual corallites reflect the successive upward growth of the colony surface and are analogous to bands of density variation reported from modern z corals (Knutson et al., 1972; Lough and Cooper, 2011). The density bands reflect the coral's response to environmental changes in growth conditions, commonly seasonal, and have, therefore, been used to create multi-annual chronologies and to make reconstructions of environmental change during the last few centuries (Felis and Pätzold, 2004). In contrast to records from modern corals, the couplets of high and low density bands seem to not represent necessarily 1 year of coral growth, because the $\delta^{18} \mathrm{O}$ cycles do not consistently correspond with the density couplets. Instead, we observe corals from the same site of growth where the HDBs coincide with the most positive, intermediate or the most negative $\delta^{18} \mathrm{O}$ values. Although there is no evidence for the asynchronies resulting from distortions of the bands in the X-ray images, the asynchronies of the density bands and stable isotope cycles bear some risk of representing an artifact of our age models which are based on the most positive $\delta^{18} \mathrm{O}$ values to define the beginning of each year, i.e. the winter temperature minimum. This assumption is only valid, however, under the premise of a dominant temperature control on the $\delta^{18} \mathrm{O}$ values with no or subordinate isotope effects related to evaporation and precipitation. In our material, this assumption is valid for the following three reasons: (1) no evidence exists in the cyclic isotope patterns for some of the cycles to be inverted from being controlled by SST to effects related to evaporation and precipitation. Rather, the $\delta^{18} \mathrm{O}$ cycles are regular, and do not exhibit any erratic pattern on an annual basis as described for a recent Solenastrea from Florida Bay subject to variable evaporation (Swart et al., 1996; Fig. 4). (2) Within individual specimens, the cycles of $\delta^{18} \mathrm{O}$ and $\delta^{13} \mathrm{C}$ exhibit consistent phase relationships which implies the driver of $\delta^{18} \mathrm{O}$ variability, likely SST, to have been systematically related to an independent environmental parameter, e.g. cloud cover and/or DIC changes due to river discharge in a rainy season or variable symbiont photosynthesis and upwelling, and (3) the amount of SST seasonality inferred from the $\delta^{18} \mathrm{O}$ values is fully consistent with modern seasonality (Leder et al., 1996; Smith, 2006). For these three inferences we suggest the oxygen isotope cycle to represent the more reliable internal chronology than the patterns of density banding, and the rhythm of density banding to have been variable from coral to coral and to some degree within corals. Disparities in skeletal growth rhythms have been reported recently from female and male colonies within one taxon (Porites panamensis), with female colonies growing slower and calcification rates being lower than in males (Cabral-Tena et al., 2013). Fossil coral specimens from the same site displaying reciprocal calcification rhythms relative to the oxygen isotope cycles may, therefore, reflect gender differences as well. Sex proportions of female: male colonies in the modern $P$. panamensis are 2: 1 (Cabral-Tena et al., 2013), however, our set of data is too small for a statistical evaluation, and gender differences are not documented in the skeleton. Nonetheless, the observed variations in calcification are likely not gender specific, because in some specimens no relationship exists between the $\delta^{18} \mathrm{O}$ cycle and the rhythm of growth banding, whereas it changes in others from the summer mode of HDB formation to the winter mode or vice versa upon continual growth. This is particularly obvious in records of long time series (Fig. 4, Tables 2, 3). Interestingly, the timing of the density bands corresponds with annual extension rate (and calcification rate). Small extension rates coincide with HDBs formed during summer $\left(R^{2}=0.50 ; p=0.002\right)$, intermediate extension rates with an irregular timing of the HDBs, and large extension rates with the predominance of winter HDBs $\left(R^{2}=0.56 ; p=0.001\right.$; Fig. 9). Bulk density also displays relationships with the chronology of the HDBs: a high summer HDB portion corresponds with high density $\left(R^{2}=0.50\right.$; $p=0.029)$, and high winter HDB portions with low bulk density $\left(R^{2}=0.38 ; p=0.012\right)$. With regard to calcification rate, corals having winter HDBs have the highest calcification rates $\left(R^{2}=0.52 ; p=0.003\right)$ and those with summer HDBs have the lowest calcification rates $\left(R^{2}=0.41\right.$; $p=0.014)$. This overall relationship differs from modern $\mathrm{z}$ corals of the Western Atlantic region which have summer HDBs but, on average, higher rates of extension and higher density than the fossil corals (own data base, not shown). From this difference we deduce the variability in calcification to be not so much related to gender but rather to the type 
of growth environment. Interestingly, in a modern reef site from the Red Sea, a distinct water-depth effect on extension rate and the timing of the HDB has been reported (Klein et al., 1993). At a depth of $3 \mathrm{~m}$ extension rates are highest and the HDB is formed during winter, whereas at $51 \mathrm{~m}$ of water depth extension rates are at their lowest and the HDB is formed during summer. This corresponds with a decrease of the phototrophy/heterotrophy ratio $(\mathrm{P} / \mathrm{H})$ reflected in $\delta^{13} \mathrm{C}$ (Klein et al., 1993). This shift of the timing is consistent with the data from the Florida fossil $\mathrm{z}$ corals, however, we rule out any water-depth effect, because repeated shifts of the timing of the HDB, and likely also changes in extension rate, are present at the level of single $\mathrm{z}$ coral specimens and not between specimens or sites only. Rather, the fossil data may document changes in the $\mathrm{P} / \mathrm{H}$ ratio due to turbidity and or food supply for heterotrophic feeding.

In addition to the oxygen isotope signal, the carbon stable isotopic signal of the corals displays a more or less distinct cyclic variation with the same wavelength as the oxygen isotope cycle though variably phase shifted. For this reason, it can be considered an annual signal as well. For evaluating the principal driver of $\delta^{13} \mathrm{C}$ variability in the fossil z corals, we consider the phase relationships of the $\delta^{18} \mathrm{O}$ and $\delta^{13} \mathrm{C}$ cycles expressed by the significant correlation coefficients $(r)$. They differ among specimens with values between $r=+1$ (=in phase) and $r=-1$ (=in antiphase). A clear negative linear relationship of $r$ exists with mean annual $\delta^{18} \mathrm{O}$ values $\left(R^{2}=0.28 ; p=0.050\right)$, whereas there is no welldefined relationship with the seasonal means: mean winter $\delta^{18} \mathrm{O}\left(R^{2}=0.22 ; p=0.087\right)$ and mean summer $\left(R^{2}=0.08\right.$; $p=0.317$; Fig. 5). This suggests specimens recording rather temperate temperatures and cold winters to have the $\delta^{13} \mathrm{C}$ cycles in antiphase with the $\delta^{18} \mathrm{O}$ cycles, i.e. specimens reflecting cold winter periods have the $\delta^{13} \mathrm{C}$ minimum during winter and vice versa.

\subsection{Upwelling as a driver of high skeletal productivity?}

Enhanced upwelling peripheral to the Florida platform causing cool and nutrient-enriched waters to flush the platform was suggested earlier as a cause for high skeletal productivity during the Pliocene and Pleistocene interglacials. This reconstruction was based on taxonomical, paleoecological and taphonomical data (Allmon, 2001; Allmon et al., 1995, 1996; Emslie and Morgan, 1994; Jones and Allmon, 1995). Most conspicuous is the occurrence of the cormorant bed from the Pliocene, illustrating events of mass mortality in seabirds depending on upwelling (Emslie and Morgan, 1994). For the cormorant bed we tend to infer the upwelling to have been intermittent. Stable isotope evidence found in molluscan shells, however, remains inconclusive with regard to the origin of high productivity (Jones and Allmon, 1995; Tao and Grossman, 2010). In contrast to earlier work, we use a positive correlation of bulk $\delta^{18} \mathrm{O}$ and bulk $\delta^{13} \mathrm{C}$ as a signature of upwelling (Figs. 3, 10), which documents the combined effects of SST cooling and enhanced organic productivity on skeletal carbonate production (Berger and Vincent, 1986). The $\delta^{13} \mathrm{C}$ in corals is controlled by a number of factors, and the identification of single factors driving $\mathrm{z}$ coral $\delta^{13} \mathrm{C}$ is not currently possible (Swart, 1983). Most important are the activity of the photosymbionts relative to heterotrophic feeding $(\mathrm{P} / \mathrm{H}$ ratio) and $\delta^{13} \mathrm{C}$ of the DIC in ambient seawater (Klaus et al., 2013; Swart, 1983; Swart et al., 2010). Organic production by zooxanthellae and plankton preferentially consumes ${ }^{12} \mathrm{C}$, driving coral skeletal $\delta^{13} \mathrm{C}$ towards more positive values (Berger and Vincent, 1986; Swart, 1983). A positive bulk skeletal $\delta^{13} \mathrm{C}$ will, therefore, reflect either a high longer-term $\mathrm{P} / \mathrm{H}$ ratio, organic production, or a combination of both, and specimens displaying positive bulk skeletal $\delta^{13} \mathrm{C}$ in conjunction with positive bulk $\delta^{18} \mathrm{O}$ values will correspondingly reflect increased photosymbiont activity during cool years or prolonged upwelling. In order to sort out the principal driving mechanism, we have identified two endmember scenarios in the isotope and calcification data (Fig. 10). Endmember 1 is represented by $\mathrm{z}$ corals with the most negative bulk $\delta^{18} \mathrm{O}$ and $\delta^{13} \mathrm{C}$ values, low $\Delta \delta^{18} \mathrm{O}$ and positive correlation of the sub-annually resolved $\delta^{18} \mathrm{O}$ and $\delta^{13} \mathrm{C}$ data (positive $r$ ). We suggest endmember scenario 1 to represent a hot water situation with low organic productivity and low seasonality; maximum organic productivity occurred during winter. Annual skeletal extension rates were low, bulk density high, and bulk calcifications rates were low; the HDB formed during summer, likely in parallel with lowest extension rates. Endmember 2 has the most positive bulk $\delta^{18} \mathrm{O}$ and $\delta^{13} \mathrm{C}$ values, high $\Delta \delta^{18} \mathrm{O}$ and negative $r$. Annual skeletal extensions rates were high but bulk density low; annual calcification rates were high as well, and the HDB formed during winter. Relative to endmember 1 , it represents a more temperate situation with high bulk organic productivity and high temperature seasonality; maximum organic production occurred during summer (Fig. 10).

Low organic productivity in endmember 1 is likely an effect of hot, oligotrophic surface waters as indicated by combined negative bulk $\delta^{18} \mathrm{O}$ and $\delta^{13} \mathrm{C}$. Maximum symbiont activity and skeletal calcification occurred during winter, whereas they were low during summer time, likely because light saturation was reached at excessive summer SSTs causing photoinhibition, bleaching or expulsion of photosynthetic algae (McConnaughey, 1989). A shallow depth of growth of the corals seems not to be the crucial factor here, because many corals record fluctuations between both endmember stages (Fig. 4). Expulsion of symbiotic algae is perhaps the most likely cause because modern Solenastrea dominating our samples is known to be facultatively zooxanthellate (Allmon, 1992). Under the cooler annual SSTs of endmember 2 , organic productivity and skeletal calcification were high, particularly during summer. Organic production, planktonic and/or zooxanthellate, were on average higher than in scenario 1 , and maximum production during summer likely reflects the positive interference of planktonic and zooxan- 
thellate productivity on skeletal $\delta^{13} \mathrm{C}$ during the warm and sunny season in a context of longer-term upwelling. Because recorded SST seasonality was high under these conditions, upwelling is likely to have been less intense during summer or to have been complemented by pronounced winter cooling. Winter cooling is compatible with the recent upwelling systems on the western Florida shelf, i.e. a positive interaction of an intensified LC and wind systems favouring Ekman transport of subsurface waters onto the shelf and into the shallow water zone (Fernald and Purdum, 1981; Li and Weisberg, 1999). This inference is in agreement with notions of an intensified LC during interglacials (Nürnberg et al., 2008). The high sea levels during interglacials may have further promoted intrusions of nutrient-rich water masses in the shallow water zone. In present-day Florida, exceptionally wet and cool winter seasons also occur during El Niño events. Subdecadal, El Niño-type cyclicity has been shown to be present in sclerochronology records from corals in Florida and the Pacific and may explain the interannual variability of our data sets (Roulier and Quinn, 1995; Watanabe et al., 2011).

With regard to the systematics of $\mathrm{z}$ coral calcification, it is important to note that the formation of the HDB dates during the period of minimum organic production, likely minimum zooxanthellate activity, in both endmember scenarios. We conclude the HDB is, therefore, the expression of maximum skeletal density developed during periods of minimum skeletal extension and minimum calcification rates, also because the fossil $\mathrm{z}$ corals having small bulk extension rates have the highest bulk density but minimal rates of skeletal extension and calcification. This calcification model is compatible with modern $\mathrm{z}$ coral calcification patterns (CarricartGanivet, 2004) and fits the environmental reconstructions for the two endmember scenarios. Endmember 2 reflects growth conditions more suitable to $\mathrm{z}$ coral growth than endmember 1 , however, endmember 2 represents a situation with more moderate SSTs than endmember 1 . As suggested in previous studies (Brachert et al., 2013; Worum et al., 2007), our work confirms coral calcification to be non-linear, and coral growth during Pliocene and Pleistocene interglacials to have occurred at high temperatures beyond optimum as reflected by low calcification.

Although Pliocene global average temperature was higher than today, episodic upwelling may have provided SSTs on Florida platform variably protected from overheating (endmember 2).

But upwelling is generally ascribed as an adverse condition on $\mathrm{z}$ coral growth and coral reef accretion because the upwelling deep-water masses potentially cause cold reef kills, impose nutrient stresses and impede carbonate cementation and skeletal calcification through phosphate poisoning and low pH (Hallock, 1988; Hallock and Schlager, 1986; Manzello et al., 2014). These negative effects, however, may be mitigated depending on the intra-annual timing of seasonal upwelling (Chollett et al., 2010), or if upwelling waters derive from rather shallow sources (Riegl and Piller, 2003). In agreement with our inferences regarding calcification in a context of upwelling (endmember 2), a study on z coral calcification in the Galapagos upwelling zone found a negative effect on density but not so on extension rates and calcification rates which were higher than expected from known relationships (Manzello et al., 2014).

Our data set documents specimens representing the two endmember situations to occur at one single sampling site and the two endmember situations to be recorded even by one single coral specimen (Fig. 4). Therefore, the changes of the two endmember conditions occurred on the time scale of a few years to decades which seems to have created suboptimal environmental conditions for most $\mathrm{z}$ coral taxa. The abundant occurrence of the eurytopic Solenastrea, which is also tolerant to high turbidity, also suggests the platform not to have been an ideal refuge for $\mathrm{z}$ coral growth within the Western Atlantic warm pool as it may be the case in an upwelling regime. In contrast to the global, long-term trend of seawater $\delta^{18} \mathrm{O}$ (Zachos et al., 2001), interglacial $\delta^{18} \mathrm{O}$ values of mollusk and $\mathrm{z}$ corals from Florida platform became increasingly negative over time which implies an increasing moisture import (Brachert et al., 2014), and likely a decrease in upwelling intensity towards the present. The oldest specimen (age 3.2 Ma; Table 1) investigated during this study represents a rather continuous record of endmember 2 for $\sim 50$ years of duration (Fig. $4 \mathrm{~d}$ ). More records are needed, however, to test if this is a robust temporal trend.

It should be noted that modern $\mathrm{z}$ corals at the Florida Reef Tract form their HDBs during the summer season, and therefore, their calcification patterns resemble the endmember 1 situation described in this study. This may possibly imply that further warming of the region will endanger coral growth.

\section{Conclusions}

1. Z coral skeletons of middle Pliocene to early Pleistocene age from the Florida platform were found in a preservation suitable for stable isotope proxy analysis $\left(\delta^{13} \mathrm{C}, \delta^{18} \mathrm{O}\right)$ and measurements of skeletal calcification using annual extension rates and bulk density.

2. High organic production recorded by the positive bulk $\delta^{13} \mathrm{C}$ and $\delta^{18} \mathrm{O}$ signals is likely an effect of upwelling of nutrient-rich and cool subsurface waters. Upwelling had a mitigating effect on otherwise hot SSTs which likely promoted enhanced $\mathrm{z}$ coral calcification rates.

3. Episodes of upwelling occurred with a few years to tens of years of duration and alternated with periods of nonupwelling. This situation is likely the reason for the unique z coral fauna dominated by eurytopic Solenastrea being also tolerant to turbid water. 
4. Periods with upwelling and without upwelling differ with regard to the signatures of skeletal calcification. Skeletal sections grown during upwelling have low bulk skeletal density but large annual growth increments reflecting high annual calcification rates. The growth bands of high density (HDB) formed during the cool season (endmember scenario 2). Skeletons grown during periods without upwelling have generally high bulk skeletal density but small annual growth increments reflecting low annual calcification rates and the HDB formed in the warm season (endmember scenario 1).

5. We do not know yet whether periods of upwelling were systematically of longer duration during interglacials of the more distant geological past, but the oldest coral record available likely documents the longest continuous episode of endmember scenario 2 ( $\sim 50$ years).

6. Published proxy data and calcification records from recent Florida $\mathrm{z}$ corals (reef tract) have many traits in common with the fossils of endmember scenario 1 . For this reason we suggest they may be endangered by future anthropogenic ocean warming.

7. The z corals display density bands consistent with skeletal growth stages but the timing of the density bands was not regular on an annual basis. It varies within specimens and differs among specimens of a single site or between different time slices. For this reason, it is not necessarily suited for developing internal chronologies and warrants a need after a critical re-evaluation of many modern coral chronologies.

Acknowledgements. We thank Edward Petuch (Florida Atlantic University, Boca Raton, USA) and Aron Böcker (Leipzig University, Germany) for sharing with us sampling material. Janice M. Lough (AIMS Townsville, Australia) carefully edited an earlier version of this manuscript. We also warmly thank J. Cortés (San José, Costa Rica), C. Perrin (Moulis, France) and an anonymous referee for their constructive comments on the discussions paper. Kurt Schubert (Leipzig, Germany) prepared the coral slices and Jörg Lenzner (University of Leipzig, Germany) made the SEM micrographs. Funding by the Deutsche Forschungsgemeinschaft is gratefully acknowledged (BR 1153/13-1).

Edited by: W. Kiessling

\section{References}

Allmon, W. D.: Whence southern Florida Plio-Pleistocene shell beds?, in: Plio-Pleistocene stratigraphy and paleontology of southern Florida, edited by: Scott, T. M. and Allmon, W. D., Florida Geological Survey Special Publication, 36, Florida Geological Survey, Tallahassee, 1992.
Allmon, W. D.: Nutrients, temperature, disturbance, and evolution: a model for the late Cenozoic marine record of the western Atlantic, Palaeogeogr. Palaeocl., 166, 9-26, 2001.

Allmon, W. D., Spizuco, M. P., and Jones, D. S.: Taphonomy and paleoenvironment of two turritellid-gastropod-rich beds, Pliocene of Florida, Lethaia, 28, 75-83, 1995.

Allmon, W. D., Emslie, S. D., Jones, D. S., and Morgan, G. S.: Late Neogene oceanographic change along Floridas west coast: evidence and mechanisms, J. Geol., 104, 143-162, 1996.

Andrews, J. E.: Geochemical indicators of depositional and early diagenetic facies in Holocene carbonate muds, and their preservation potential duringstabilisation, Chem. Geol., 93, 267-289, 1991.

Banks, J. E.: Geologic history of the Florida-Bahama platform, Transactions of the Gulf Coast Association of Geological Societies, 17, 261-264, 1967.

Berger, W. H. and Vincent, E.: Deep-sea carbonates: reading the carbon-isotope signal, Geol. Rundsch., 75, 249-269, 1986.

Böcker, A.: Interannual and seasonal climate variability recorded by reef corals, Plio/Pleistocene (Florida) and Mio/Pliocene (Dominican Republic), Dissertation, Fakultät für Physik und Geowissenschaften, Universität Leipzig, Leipzig, 2014.

Brachert, T. C., Reuter, M., Felis, T., Kroeger, K. F., Lohmann, G., Micheels, A., and Fassoulas, C.: Porites corals from Crete (Greece) open a window into Late Miocene (10 Ma) seasonal and interannual climate variability, Earth Planet. Sc. Lett., 245, 8194, 2006a.

Brachert, T. C., Reuter, M., Kroeger, K. F., and Lough, J.: Coral growth bands: A new and easy to use paleothermometer in paleoenvironment analysis and paleoceanography (late Miocene, Greece), Paleoceanography, 21, PA4217, doi:10.1029/2006PA001288, 2006b.

Brachert, T. C., Reuter, M., Krüger, S., Böcker, A., Lohmann, H., Mertz-Kraus, R., and Fassoulas, C.: Density banding in corals: barcodes of past and current climate change, Coral Reefs, 32, 1013-1023, 2013.

Brachert, T. C., Reuter, M., Krüger, S., Lohmann, H., Petuch, E. J., and Klaus, J. S.: A 4.2 Million years record of interglacial paleoclimate from sclerochronological data of Florida carbonate platform (Early Pliocene to recent), Global Planet. Change, 120, 54-64, 2014.

Brachert, T. C., Reuter, M., Krüger, S., Klaus, J. S., Helmle, K., and Lough, J. M.: Low Florida coral calcification rates in the PlioPleistocene, Biogeosciences Discuss., under review, 12, 20515 20555, doi:10.5194/bgd-12-20515-2015, 2015.

Budd, A. F., Fukami, H., Smith, N. D., and Knowlton, N.: Taxonomic classification of the reef coral family Mussidae (Cnidaria: Anthozoa: Scleractinia), Zool. J. Linn. Soc.-Lond., 166, 465529, 2012.

Buddemeier, R. W., Maragos, J. E., and Knutson, D. W.: Radiographic studies of ree coral exoskeletons: rates and patterns of coral grwoth, J. Exp. Mar. Biol. Ecol., 14, 179-200, 1974.

Cabral-Tena, R. A., Reyes-Bonilla, H., Lluch-Cota, S., Paz-Garcia, D. A., Calderon-Aguilera, L. E., Norzagary-Lopez, O., and Balart, E. F.: Different calcification rates in males and females of the coral Porites panamensis in the Gulf of California, Mar. Ecol.-Prog. Ser., 476, 1-8, 2013. 
Cantin, N. E., Cohen, A. L., Karnauskas, K. B., Tarrant, A. M., and McCorkle, D. C.: Ocean warming slows coral growth in the central Red Sea, Science, 329, 322-325, 2010.

Carricart-Ganivet, J. P.: Sea surface temperature and the growth of the West Atlantic reef-building coral Montastraea annularis, J. Exp. Mar. Biol. Ecol., 302, 249-260, 2004.

Chollett, I., Mumby, P. J., and Cortes, J.: Upwelling areas do not guarantee refuge for coral reefs in a warming world, Mar. Ecol.Prog. Ser., 416, 47-56, 2010.

Constantz, B. R.: The primary surface area of corals and variations in their susceptibility to diagenesis, in: Reef Diagenesis, edited by: Schroeder, J. H. and Purser, B. H., Springer-Verlag, New York, 1986.

De'ath, G., Lough, J. M., and Fabricius, K. E.: Declining Coral Calcification on the Great Barrier Reef, Science, 323, 116-119, 2009.

De'ath, G., Fabricius, K., and Lough, J.: Yes - Coral calcification rates have decreased in the last twenty-five years!, Mar. Geol., 346, 400-402, 2013.

Dodge, R. E., Szmant, A. M., Garcia, R., Swart, P. K., Forester, A., and Leder, J. J.: Skeletal structural basis of density banding in the reef coral Montastrea annularis, Guam, 186-195, 1992.

Dowsett, H. J. and Cronin, T. M.: High eustatic sea level during the middle Pliocene: Evidence from the southeastern U.S. Atlantic Coastal Plain, Geology, 18, 435-438, 1990.

DuBar, J. R.: Neogene stratigraphy of southwestern Florida, Transactions of the Gulf Coast Association of Geological Societies, 8, 129-155, 1958.

Elizalde-Rendon, E. M., Horta-Puga, G., Gonzalez-Diaz, P., and Carricart-Ganivet, J. P.: Growth characteristics of the reefbuilding coral Porites astreoides under different environmental conditions in the Western Atlantic, Coral Reefs, 29, 607-614, 2010.

Emslie, S. D. and Morgan, G. S.: A Catastrophic Death Assemblage and Paleoclimatic Implications of Pliocene Seabirds of Florida, Science, 264, 684-685, 1994.

Felis, T. and Pätzold, J.: Corals as climate archive, in: The KIHZ project: Towards a synthesis of Holocene proxy data and climate models, edited by: Fischer, H., Kumke, T., Lohmann, G., Flöser, G., Miller, H., von Storch, H., and Negendank, J. F. W., GKSS School of Environmental Research, Springer-Verlag, Berlin, 2004.

Fernald, E. A. and Purdum, E. D.: Atlas of Florida, University Press of Florida, Tallahassee, FL, 1981.

Friedman, I. and O'Neil, J. R.: Compilation of stable isotope fractionation factors of geochemical interest, in: Data of geochemistry, edited by: Fleischer, M., Chapter K. K., 6th edition, US Geological Survey Professional Papers 440 KK, 1977.

Halley, R. B. and Roulier, L. M.: Reconstructing the history of eastern and central Florida Bay using mollusk-shell isotope records, Estuaries, 22, 358-368, 1999.

Hallock, P.: The role of nutrient availability in bioerosion: consequences to carbonate buildups, Palaeogeogr. Palaeocl., 63, 275291, 1988.

Hallock, P. and Schlager, W.: Nutrient excess and the demise of coral reefs and carbonate platforms, Palaios, 1, 389-398, 1986.

Helmle, K. P., Kohler, K. E., and Dodge, R. E.: The coral Xradiograph densitometry system: CoralXDS, Nova Southeastern University, Fort-Lauderdale-Davie, 2002.
Highsmith, R. C.: Coral growth rates and environmental control of density banding, J. Exp. Mar. Biol. Ecol., 37, 105-125, 1979.

Joachimski, M. M.: Subaerial exposire and depoasition of shallowing upward sequences: evidence from stable isotopes of Purbeckian peritidal carbonates (basal Cretaceous), Swiss and French Jura Mountains, Sedimentology, 41, 805-824, 1994.

Jones, D. S. and Allmon, W. D.: Records of upwelling, seasonality and growth in stable-isotope profiles of Pliocene mollusk shells from Florida, Lethaia, 28, 61-74, 1995.

Jones, D. S., Macfadden, B., Webb, S. D., Mueller, P. A., Hodell, D. A., and Cronin, T. M.: Integrated chronostratigraphy of a classic Pliocene fossil site in Florida: Linking marine and terrestrial biochronologies, J. Geol., 99, 637-648, 1991.

Klaus, J. S., Murray, S. T., Swart, P. K., and McNeill, D. F.: Resource partitioning and paleoecology of Neogene free-living corals as determined from skeletal srable isotope composition, B. Mar. Sci., 89, 937-954, 2013.

Klein, R., Pätzold, J., Wefer, G., and Loya, Y.: Seasonal variations in the stable isotopic composition and the skeletal density pattern of the coral Porites lobata (Gulf of Eilat, Red Sea), Mar. Biol., 112, 259-263, 1992.

Klein, R., Pätzold, J., Wefer, G., and Loya, Y.: Depth-related timing of density band formation in Porites spp. corals from the Red Sea inferred from X-ray chronology and stable isotope composition, Mar. Ecol.-Prog. Ser., 97, 99-104, 1993.

Knutson, D. W., Buddemeier, R. W., and Smith, S. V.: Coral chronometers: seasonal growth bands in reef corals, Science, 177, 270-272, 1972.

Le Tissier, M. D. A. A., Clayton, B., Brown, B. E., and Spencer Davis, P.: Skeletal correlates of coral density banding and an evaluation of radiography as used in sclerochronology, Mar. Ecol.-Prog. Ser., 110, 29-44, 1994.

Leder, J. J., Szmant, A. M., and Swart, P. K.: The effect of prolonged "bleaching" on skeletal banding and stable isotopic composition in Montastrea annularis, Coral Reefs, 10, 19-27, 1991.

Leder, J. J., Swart, P. K., Szmant, A., and Dodge, R. E.: The origin of variations in the isotopic record of scleractinian corals: 1. Oxygen, Geochim. Cosmochim. Ac., 60, 2857-2870, 1996.

Li, Z. and Weisberg, R. H.: West Florida shelf response to upwelling favorable wind forcing: Kinematics, J. Geophys. Res. 104, 13507-13527, 1999.

Locker, S. D. and Doyle, L. J.: Neogene to recent stratigraphy and depositional regimes of the northwest Florida inner continental shelf, Mar. Geol., 104, 123-138, 1992.

Lough, J. M.: Coral calcification from skeletal records revisited, Mar. Ecol.-Prog. Ser., 373, 257-264, 2008.

Lough, J. M. and Cooper, T. F.: New insights from coral growth band studies in an era of rapid environmental change, Earth-Sci Rev., 108, 170-184, 2011.

Manzello, D. P., Enochs, I. C., Bruckner, A., Renaud, P. G., Kolodziej, G., Budd, D. A., Carlton, R., and Glynn, P. W.: Galapagos coral reef persistence after ENSO warming across an acidification gradient, Geophys. Res. Lett., 41, 9001-9008, 2014.

McConnaughey, T.: ${ }^{13} \mathrm{C}$ and ${ }^{18} \mathrm{O}$ isotopic disequilibrium in biological carbonates: I. Patterns, Geochim. Cosmochim. Ac., 53, 151$162,1989$.

McGregor, H. V. and Gagan, M. K.: Diagenesis and geochemistry of Porites corals from Papua New Guinea: Implications for pale- 
oclimate reconstruction, Geochim. Cosmochim. Ac., 67, 21472156, 2003.

Meeder, J. F.: A field guide with road log to "The Pliocene fossil reef of southwest Florida", Miami, 19 pp., 1979.

Miller, K. G., Wright, J. D., Browning, J. V., Kulpecz, A., Kominz, M., Naish, T. R., Cramer, B. S., Rosenthal, Y., Peltier, W. R., and Sosdian, S.: High tide of the warm Pliocene: Implications of global sea level for Antarctic deglaciation, Geology, 1-4, doi:10.1130/G32869.1, 2012.

Norzagary-Lopez, O., Calderon-Aguilera, L. E., Hernandez-Ayon, J. M., Reyes-Bonilla, H., Carricart-Ganivet, J. P., Cabral-Tena, R. A., and Balart, E. F.: Low calcification rates and calcium carbonate production in Porites panamensis at its northernmost geographic distribution, Mar. Ecol., 2014, 1-12, 2014.

Nothdurft, L. and Webb, G.: Microstructure of common reefbuilding coral genera Acropora, Pocillopora, Goniastrea and Porites: constraints on spatial resolution in geochemical sampling, Facies, 53, 1-26, 2007.

Nothdurft, L. D. and Webb, G. E.: Earliest diagenesis in scleractinian coral skeletons: implications for palaeoclimate-sensitive geochemical archives, Facies, 55, 161-201, 2009.

Nürnberg, D., Ziegler, M., Karas, C., Tiedemann, R., and Schmidt, M. W.: Interacting Loop Current variability and Mississippi River discharge over the past 400 Â kyr, Earth Planet. Sc. Lett., 272, 278-289, 2008.

O’Brien, C. L., Foster, G. L., Martinez-Boti, M. A., Abell, R., Rae, J. W. B., and Pancost, R. D.: High sea surface temperatures in tropical warm pools during the Pliocene, Nat. Geosci., 7, 606611, 2014.

Paillard, D., Labeyrie, L., and Yiou, P.: Macintosh program performs time-series analysis, EOS Transactions of the American Geophysical Union, 77, p. 379, 1996.

Perrin, C.: Diagenèse précoce des biocristaux carbonatés : transformations isominérales de l'aragonite corallienne, Bulletin de la Société Géologique de France, 175, 95-106, 2004.

Petuch, E. J.: Notes on the molluscan paleontology of the Pinecrest Beds at Sarasota, Florida with the description of Pyruella, a stratigraphically important new genus, P. Acad. Nat. Sci. Phila., 134, 12-30, 1982.

Petuch, E. J. and Roberts, C. E.: The geology of the Everglades and adjacent areas, CRC Press, New York and Boca Raton, 2007.

Pitts, P. A. and Smith, N. P.: An investigation of summer upwelling across central Florida's Atlantic coast: the case for wind stress forcing, J. Coast. Res., 13, 105-110, 1997.

Reuter, M., Brachert, T. C., and Kroeger, K. F.: Diagenesis of growth bands in fossil scleractinian corals: Identification and modes of preservation, Facies, 51, 155-168, 2005.
Riegl, B. and Piller, W. E.: Possible refugia for reefs in times of environmental stress, Int. J. Earth Sci., 92, 520-531, 2003.

Roulier, L. M. and Quinn, T. M.: Seasonal- to decadal-scale climatic variability in southwest Florida during the middle Pliocene: Inferences from a coralline stable isotope record, Paleoceanography, 10, 429-443, 1995.

Smith, J. M.: Geochemical Signatures in the Coral Montastraea: Modern and Mid-Holocene Perspectives, Doctor of Philosophy Dissertation, College of Marince Science, University of South Florida, Miami, 126 pp., 2006.

Swart, P. K.: Carbon and oxygen isotope fractionation in scleractinian corals: A review, Earth-Sci. Rev., 19, 51-80, 1983.

Swart, P. K., Healy, G. F., Dodge, R. E., Kramer, P., Hudson, J. H., Halley, R. B., and Robblee, M. B.: The stable oxygen and carbon isotopic record from a coral growing in Florida Bay: a 160 year record of climatic and anthropogenic influence, Palaeogeogr. Palaeocl., 123, 219-237, 1996.

Swart, P. K., Greer, L., Rosenheim, B. E., Moses, C. S., Waite, A. J., Winter, A., Dodge, R. E., and Helmle, K.: The 13C Suess effect in scleractinian corals mirror changes in the anthropogenic $\mathrm{CO}_{2}$ inventory of the surface oceans, Geophys. Res. Lett., 37, L05604, doi:10.1029/2009g1041397, 2010.

Tao, K. and Grossman, E. L.: Origin of high productivity in the Pliocene of the Florida platform: Evidence from stable isotopes, Palaios, 25, 796-806, 2010.

Watanabe, T., Suzuki, A., Minobe, S., Kawashima, T., Kameo, K., Minoshima, K., Aguilar, Y. M., Wani, R., Kawahata, H., Sowa, K., Nagai, T., and Kase, T.: Permanent El Nino during the Pliocene warm period not supported by coral evidence, Nature, 471, 209-211, 2011.

Williams, M., Haywood, A. M., Harper, E. M., Johnson, A. L. A., Knowles, T., Leng, M. J., Lunt, D. J., Okamura, B., Taylor, P. D., and Zalasiewicz, J.: Pliocene climate and seasonality in North Atlantic shelf seas, Philosophical Transactions of the Royal Society A: Mathematical, Phys. Eng. Sci., 367, 85-108, 2009.

Worum, F. P., Carricart-Ganivet, J. P., Besnon, L., and Golicher, D.: Simulation and observation of annual density banding in skeletons of Montastrea (Cnidaria: Scleractinia) growing under thermal stress associated with ocean warming, Limnol. Oceanogr., 52, 2317-2323, 2007.

Yang, H., Weisberg, R. H., Niiler, P. P., Sturges, W., and Johnson, W.: Lagrangian circulation and forbidden zone on the west Florida Shelf, Cont. Shelf Res., 19, 1221-1245, 1999.

Zachos, J., Pagani, M., Sloan, L., Thomas, E., and Billups, K.: Trends, rhythms, and aberrations in global climate $65 \mathrm{Ma}$ to present, Science, 292, 686-693, 2001. 